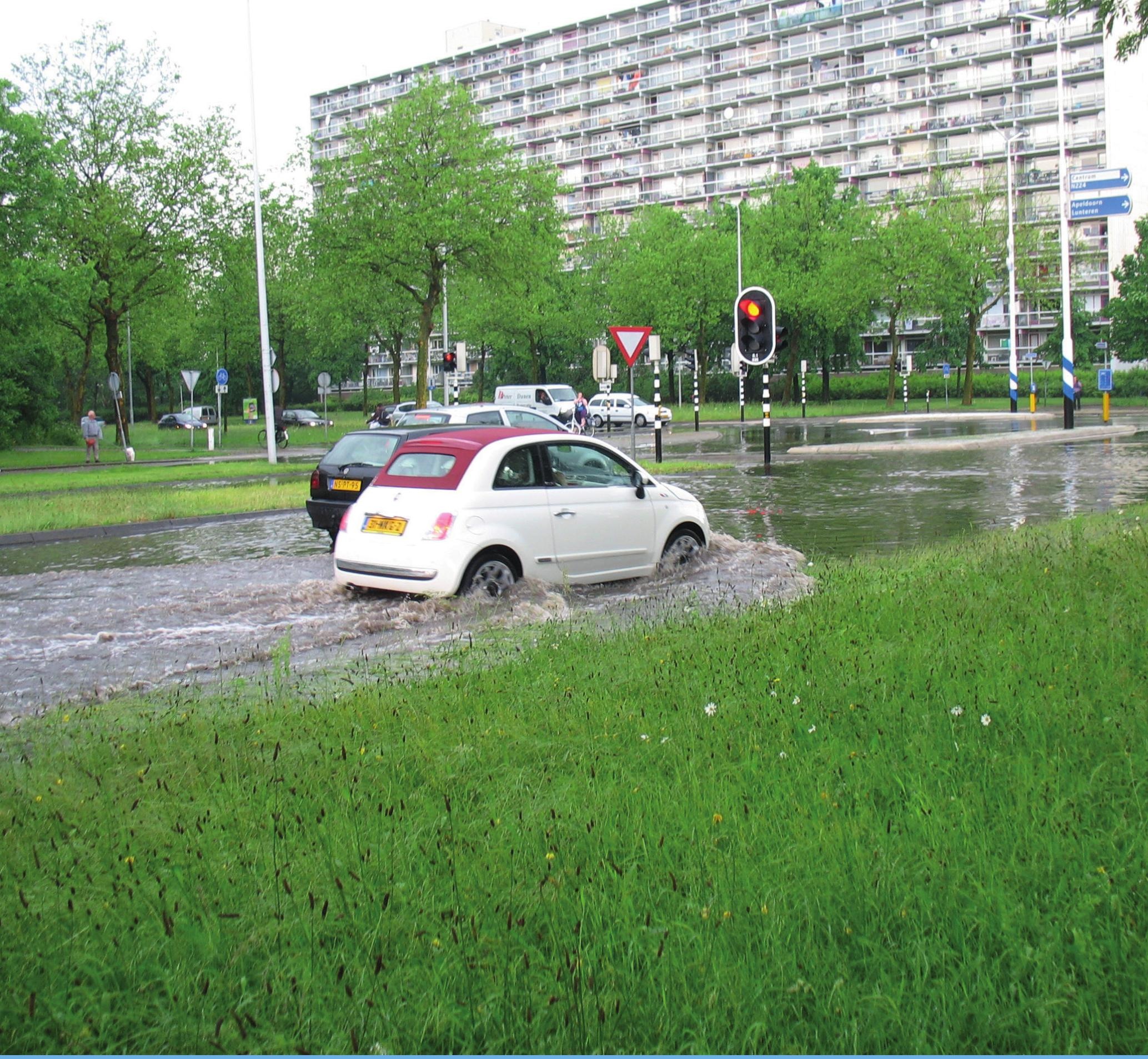

\title{
Toekomstvisie Watermuseum
}

Eerste deeladvies over nieuwe onderwerpen voor het museum

Naomi Kroon, Judith Klostermann

WAGENINGEN

UNIVERSITY \& RESEARCH 



\section{Toekomstvisie Watermuseum}

Eerste deeladvies over nieuwe onderwerpen voor het museum

Naomi Kroon, Judith Klostermann

Dit onderzoek is uitgevoerd door Wageningen Environmental Research in opdracht van en gefinancierd door de Wetenschapswinkel van Wageningen Universiteit (projectnummer 359).

Wageningen Environmental Research

Wageningen, juli 2020

Gereviewd door:

Fokke de Jong, Wageningen Environmental Research

Akkoord voor publicatie:

Derk Rademaker, teamleider van Klimaatbestendigheid

Rapport 3022

ISSN 1566-7197 
Kroon, N., J.E.M. Klostermann, 2020. Toekomstvisie Watermuseum; Eerste deeladvies over nieuwe onderwerpen voor het museum. Wageningen, Wageningen Environmental Research, Rapport 3022. 46 blz.; 11 fig.; 2 tab.; 75 ref.

Dit is een deeladvies voor het Nederlands Watermuseum met als doel de belangrijke trends in Nederland te beschrijven die te maken hebben met water. Tevens wordt basiskennis beschreven van de essentie van water, de waterkringloop en de waterketen, die het museum ook zou kunnen gebruiken. Ten slotte wordt in het procesadvies praktisch advies gegeven op het gebied van inhoud/boodschap, monitoring en externe relaties/partnerships. De trends die besproken worden, vallen binnen drie thema's: ruimte/natuur, voedsel/landbouw en klimaatverandering. Onderwerpen zoals waterkwantiteit, waterkwaliteit, veenweideproblematiek en het waterverbruik van landbouw worden besproken. Oplossingsrichtingen worden geboden in het handelingsperspectief: hier komt aan bod wat voor eigen acties er mogelijk zijn, wat de wetenschap kan betekenen en wat voor innovaties uitkomst kunnen bieden. Meer specifiek wordt er aandacht besteed aan mitigatie, adaptatie, oplossingen voor de veenweidedaling, het gebruik van klimaatbuffers en kringlooplandbouw. De conclusie is dat de centrale boodschap voor de bezoeker moet zijn dat water een mooi en kostbaar onderdeel van Nederland is, waar we erg zuinig op moeten zijn.

Trefwoorden: water, trends, klimaat, ruimte, natuur, voedsel, landbouw, Watermuseum

Dit rapport is gratis te downloaden van https://doi.org/10.18174/534148 of op www.wur.nl/environmental-research (ga naar 'Wageningen Environmental Research' in de grijze balk onderaan). Wageningen Environmental Research verstrekt geen gedrukte exemplaren van rapporten.

2020 Wageningen Environmental Research (instituut binnen de rechtspersoon Stichting Wageningen Research), Postbus 47, 6700 AA Wageningen, T 03174807 00, www.wur.nl/environmental-research. Wageningen Environmental Research is onderdeel van Wageningen University \& Research.

- Overname, verveelvoudiging of openbaarmaking van deze uitgave is toegestaan mits met duidelijke bronvermelding.

- Overname, verveelvoudiging of openbaarmaking is niet toegestaan voor commerciële doeleinden en/of geldelijk gewin.

- Overname, verveelvoudiging of openbaarmaking is niet toegestaan voor die gedeelten van deze uitgave waarvan duidelijk is dat de auteursrechten liggen bij derden en/of zijn voorbehouden.

Wageningen Environmental Research aanvaardt geen aansprakelijkheid voor eventuele schade voortvloeiend uit het gebruik van de resultaten van dit onderzoek of de toepassing van de adviezen.

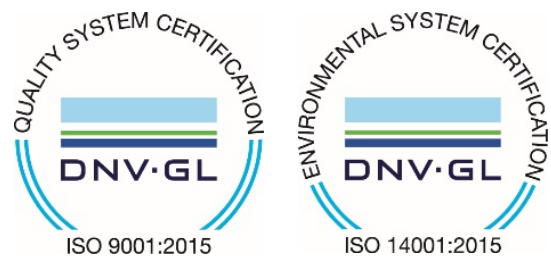

Wageningen Environmental Research werkt sinds 2003 met een ISO 9001 gecertificeerd kwaliteitsmanagementsysteem. In 2006 heeft Wageningen Environmental Research een milieuzorgsysteem geïmplementeerd, gecertificeerd volgens de norm ISO 14001.

Wageningen Environmental Research geeft via ISO 26000 invulling aan haar maatschappelijke verantwoordelijkheid.

Wageningen Environmental Research Rapport 3022 | ISSN 1566-7197

Foto omslag: Wateroverlast in Ede op 23 mei 2012 (Foto: Klostermann) 


\section{Inhoud}

$\begin{array}{ll}\text { Verantwoording } & 5\end{array}$

$\begin{array}{ll}\text { Abstract } & 7\end{array}$

$\begin{array}{ll}\text { Samenvatting } & 9\end{array}$

$\begin{array}{lrr}1 & 11\end{array}$

$1.1 \quad$ Aanleiding en doel 11

1.2 Methoden 11

1.2.1 Workshops 11

1.2.2 Literatuuronderzoek 11

1.2.3 Interviews 11

1.2.4 Vragenlijsten bezoekers $\quad 12$

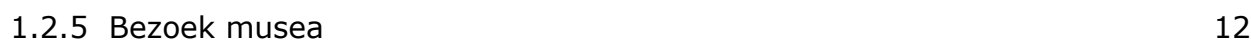

$\begin{array}{lll}1.3 & \text { Leeswijzer } & 12\end{array}$

$2 \quad$ Afbakening van de scope $\quad 13$

2.1 Keuze voor zoetwater 13

2.2 Zeven maatschappelijke trends $\quad 14$

$\begin{array}{ll}2.3 & \text { Bepaling van de scope } \\ \end{array}$

2.3.1 Selectie van inhoudelijke domeinen $\quad 15$

$\begin{array}{ll}2.3 .2 \text { Geografische schaal } & 15\end{array}$

$\begin{array}{ll}2.3 .3 \text { Tijd } & 16\end{array}$

$\begin{array}{llr}3 & \text { Basiskennis watersysteem } & 17\end{array}$

$\begin{array}{lll}3.1 & \text { Waterkringloop } & 17\end{array}$

3.2 Waterketen 18

3.3 Essentie van water voor het leven $\quad 19$

$\begin{array}{ll}3.4 & \text { Belang van water voor de mens }\end{array}$

$4 \quad$ Toekomstige veranderingen $\quad 20$

4.1 Veranderingen in ruimte en natuur in Nederland $\quad 20$

4.1.1 Ruimtegebruik in Nederland $\quad 20$

$\begin{array}{ll}4.1 .2 \text { Waterkwaliteit } & 21\end{array}$

4.1.3 Verschuiving van soorten $\quad 22$

4.1.4 Bodemdaling en veenweidegebied $\quad 22$

4.2 Voedsel/Landbouw - Europa/Nederland $\quad 24$

4.2.1 Watergebruik voor landbouw en voedselproductie $\quad 24$

4.2.2 Kringlooplandbouw $\quad 24$

$\begin{array}{ll}4.2 .3 \text { Stikstofcrisis } & 25\end{array}$

4.3 Klimaatverandering - mondiaal $\quad 26$

$\begin{array}{ll}\text { 4.3.1 Waterkwantiteit } & 26\end{array}$

4.3.2 Waterkwaliteit $\quad 27$

$\begin{array}{ll}4.3 .3 \text { Extremen } & 27\end{array}$

4.3.4 Zeespiegelstijging 27

4.3.5 Effecten klimaatverandering op landbouw - mondiaal 28

4.3.6 Effecten klimaatverandering op landbouw - Europa $\quad 28$

$\begin{array}{lll}4.4 & \text { Klimaatverandering - Nederland } & 29\end{array}$

4.4.1 Waterkwantiteit $\quad 29$

4.4.2 Waterkwaliteit 30

4.4.3 Extremen 30

4.4.4 Zeespiegelstijging 30 
5.1 Ruimte/natuur 32

5.1.1 Vernatting van veengebieden $\quad 32$

5.1.2 Inrichting en herstel natuur 32

5.1.3 Participatie in vergroenen $\quad 33$

5.2 Voedsel/landbouw $\quad 34$

5.2.1 Gedragsverandering 34

5.2.2 Kringlooplandbouw 34

5.2.3 Andere landbouwvormen 34

$\begin{array}{lll}5.3 & \text { Klimaatverandering } & 35\end{array}$

5.3.1 Mitigatie $\quad 35$

$\begin{array}{ll}5.3 .2 \text { Adaptatie } & 35\end{array}$

6

\section{Procesadvies}

6.1 Intern - boodschap en monitoring

6.2 Extern - pop-up en communicatie

Bijlage 1 Vragenlijst bezoekers

Bijlage 2 Resultaten vragenlijsten bezoekers 


\section{Verantwoording}

Rapport: 3022

Projectnummer: 5200045103

Wageningen Environmental Research (WENR) hecht grote waarde aan de kwaliteit van zijn eindproducten. Een review van de rapporten op wetenschappelijke kwaliteit door een referent maakt standaard onderdeel uit van ons kwaliteitsbeleid.

Akkoord Referent die het rapport heeft beoordeeld,

functie: Webmanager en communicatieadviseur

naam: $\quad$ Fokke de Jong

datum: 16 augustus 2019

Akkoord teamleider voor de inhoud,

naam: Derk Rademaker

datum: 21 april 2020 


\section{Abstract}

This report was commissioned by the Dutch Water Museum. This museum has indicated that it wants to innovate and wants to lead the way in the museum sector when it comes to water. This report zooms in on three subjects for which research has been conducted into important trends in the field of water which is the main theme for the museum. For each topic, action perspectives are discussed that can offer a solution to problematic trends. Finally, some process advice is offered with recommendations and practical suggestions.

Basic knowledge about the water cycle and the water chain remains an important part of the museum's story. Information about the essence of water for all living beings also remains relevant. In addition to this basic knowledge, this research explores the following domains: land use $\&$ nature, food $\&$ agriculture, and climate change. Important trends are discussed within these domains. Within the subject of land use / nature, particular attention is paid to how land is used in the Netherlands and how this may change in the future, to water quality and to how species are shifting towards the north as a result of climate change. This theme is treated within the Dutch situation. The food / agriculture domain addresses the water use for the food we eat, especially when it is produced in areas with water scarcity. Attention is also paid to the peat meadow problems. Within the theme of climate change, a distinction has been made between global trends and the effects that will impact the Netherlands. At both spatial scales there are issues with water quantity, water quality, extremes and sea level rise. The section on the global effects of climate change also highlights the effects of climate change on agriculture.

Several potential solutions are offered for each domain. Three possible solutions for peat meadow fall are discussed within land use / nature: water level fixation, underwater drainage and alternative land use. Furthermore, climate buffers are discussed as a solution for the loss of nature areas and the role of participation in the greening of the living environment is explored. Within the theme of food / agriculture, behavioural change, circular agriculture and other forms of agriculture are discussed. Finally, within the theme of climate change, mitigation is addressed, in particular the question "What can you do yourself?" Adaptation to climate change is also covered.

The process advice firstly looks at internal aspects, such as the main message that is presented to the museum visitor and the monitoring of successful and less successful displays. The core message should be that water is a beautiful and important part of The Netherlands that we need to protect. The second part of the process advice focuses on the external relations of the museum and its position in relation to other museums. Among other things, the option to organize excursions with partners is discussed here. 


\section{Samenvatting}

Dit rapport is gemaakt in opdracht van het Nederlands Watermuseum. Dit museum heeft aangegeven te willen vernieuwen en voorop te willen lopen in museumland als het gaat om het thema water. In dit rapport is ingezoomd op drie onderwerpen, waarbinnen onderzoek is gedaan naar belangrijke trends op het gebied van water als hoofdthema voor in het museum. Per onderwerp worden handelingsperspectieven besproken die een oplossing kunnen bieden voor toekomstige problemen. Ten slotte wordt er een eerste procesadvies geboden met aanbevelingen en praktische suggesties.

Basiskennis over de waterkringloop en de waterketen blijft een belangrijk onderdeel van het verhaal van het museum. Ook informatie over de essentie van water voor alle levende wezens blijft relevant. Naast deze basiskennis is dit onderzoek gericht op drie specifieke onderwerpen: ruimte/natuur, voedsel/landbouw en klimaatverandering. Binnen deze onderwerpen worden belangrijke trends besproken. Binnen het onderwerp ruimte/natuur wordt vooral aandacht besteed aan hoe ruimte in Nederland gebruikt wordt en hoe dat in de toekomst kan gaan veranderen wat betreft waterkwaliteit en hoe soorten door klimaatverandering opschuiven richting het noorden. Dit thema wordt behandeld binnen de Nederlandse situatie. Binnen het onderwerp voedsel/landbouw wordt ingegaan op watergebruik met betrekking tot het voedsel dat wij eten, vooral wanneer dit geproduceerd wordt in gebieden met waterschaarste. Ook wordt aandacht besteed aan de veenweideproblematiek. Binnen het thema klimaatverandering is onderscheid gemaakt tussen mondiale trends en de effecten die Nederland zal merken. Beide delen behandelen waterkwantiteit, waterkwaliteit, extremen en zeespiegelstijging. Het deel over de mondiale effecten van klimaatverandering belicht ook de gevolgen van klimaatverandering voor de landbouw.

Per onderwerp wordt een aantal oplossingsrichtingen geboden. Binnen ruimte/natuur worden drie mogelijke oplossingen voor veenweidedaling besproken: peilfixatie, onderwaterdrainage en alternatief landgebruik. Verder wordt er ingegaan op klimaatbuffers als oplossingsrichting voor het verlies van natuurgebieden en op de rol van participatie in het vergroenen van de leefomgeving. Binnen het thema voedsel/landbouw worden gedragsverandering, kringlooplandbouw en andere landbouwvormen besproken. Ten slotte wordt binnen het thema klimaatverandering ingegaan op mitigatie, en dan vooral vanuit de vraag 'wat kun je zelf doen?' Ook wordt er aandacht besteed aan adaptatie.

Het procesadvies is tweeledig: intern, vooral gericht op de boodschap die meegegeven wordt aan de bezoeker en de monitoring van succesvolle en minder succesvolle onderdelen. De kern hiervan is dat water een mooi en belangrijk onderdeel is van ons land waar we erg zuinig op moeten zijn. Het andere deel van het procesadvies richt zich op de externe relaties van het museum en de positie ten opzichte van andere musea. Hier wordt onder andere de optie besproken om excursies te organiseren met partners. 


\section{$1 \quad$ Inleiding}

\subsection{Aanleiding en doel}

Water en Nederland. Deze twee onderwerpen worden vaak met elkaar in verband gebracht, zowel in positieve als in negatieve zin. Neem bijvoorbeeld de watersnoodramp in 1953 of juist de internationale bekendheid van Nederlanders als het gaat om het droogleggen van polders. Nederland is dan ook een waterrijk land; het water is overal om ons heen: in rivieren, meren, sloten en plassen. Water komt op talrijke manieren voor in ons dagelijks leven. Het is onze eerste levensbehoefte, maar tegelijkertijd kan het, zeker voor laaggelegen kustgebieden zoals Nederland, een groot gevaar zijn in de vorm van overstromingen.

Allerlei onderwerpen rondom water in Nederland worden belicht in het Nederlands Watermuseum. Dit museum is gevestigd in een monumentaal pand in het Sonsbeekpark in Arnhem. Het is ontstaan uit het idee om een voorlichtingscentrum over water op te richten naar aanleiding van een opknapbeurt van de Begijnenmolen in dit park. Deze molen werd verbouwd tot museum en werd in 2004 officieel geopend. Het Watermuseum richt zich vooral op kinderen in de basisschoolleeftijd, hun ouders en grootouders. Er komen ook Duitstalige bezoekers. Het feit dat water effect heeft op zoveel verschillende aspecten van ons leven, maakt dat het Nederlands Watermuseum voor iedereen relevant is. Het is wel belangrijk voor het museum om met de tijd mee te gaan. Er zijn immers veel ontwikkelingen op het gebied van water. Daarom is in opdracht van het Watermuseum dit adviesrapport geschreven. Dit eerste advies gaat vooral over de inhoudelijke scope van het Watermuseum. Een advies over de strategische, didactische en communicatieve aanpak volgt in een tweede adviesrapport.

\subsection{Methoden}

\subsubsection{Workshops}

Tijdens het proces zijn twee workshops gehouden met de begeleidingscommissie van dit project, waar vertegenwoordigers van de WUR en het museumbestuur in zitten (Zie Figuur 1). In deze workshops zijn de toekomstige trends, de focus in plaats en tijd en de criteria voor selectie van onderwerpen bediscussieerd. Tijdens deze bijeenkomsten heeft de afbakening van de scope plaatsgevonden.

\subsubsection{Literatuuronderzoek}

Om de trends op het gebied van water in Nederland verder uit te werken, is een literatuuronderzoek uitgevoerd. Hierbij zijn actuele rapporten, documenten en wetenschappelijke artikelen geraadpleegd. Deze zijn terug te vinden in de literatuurlijst. De inhoud van dit rapport geeft de interessante onderwerpen kort weer. Belangrijke documenten komen daarom ook in kaders door het stuk heen terug. Een deel van de inhoud kan snel verouderen. Het volgende symbool geeft aan dat er meer te lezen is over een onderwerp en waar dit te vinden is:

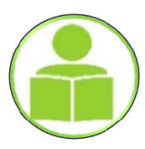

\subsubsection{Interviews}

Er zijn verschillende interviews uitgevoerd die een rol hebben gespeeld in de afbakeningen, het beschrijven van de trends en het uitwerken van het procesadvies. Er zijn personen geïnterviewd van 
de volgende organisaties: Nederlands Watermuseum, Waterschap Rijn en IJssel, WUR, KWR, Instituut Beeld en Geluid en Openluchtmuseum Arnhem.

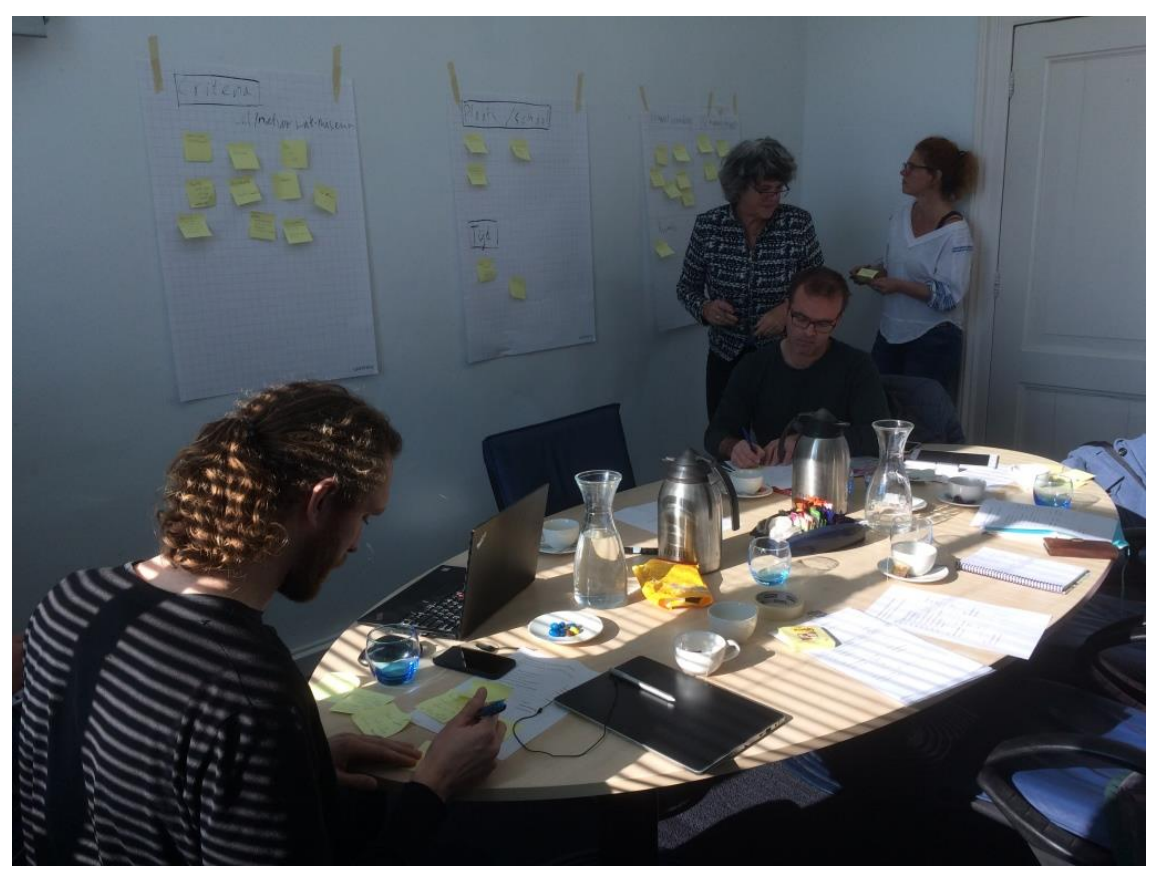

Figuur 1 Watermuseum workshop 1 op 27 februari 2019

\subsubsection{Vragenlijsten bezoekers}

Om een idee te krijgen wat bezoekers graag in het museum zouden willen zien in de toekomst, zijn vragenlijsten afgenomen bij dertig bezoekers. De vragenlijsten en resultaten zijn te vinden in de bijlagen.

\subsubsection{Bezoek musea}

Met als doel inspiratie op te doen voor de toekomst van het Watermuseum is een aantal innovatieve en moderne musea bezocht (waar bij een aantal ook een interview heeft plaatsgevonden). De lessen die geleerd kunnen worden door naar andere musea te kijken, komen vooral terug in het procesadvies. Dit aspect komt uitgebreider aan de orde in het tweede deeladvies.

\subsection{Leeswijzer}

In Figuur 2 is weergegeven hoe de komende hoofdstukken ingedeeld zijn. Eerst worden de afbakening en de keuzes daarachter behandeld (hoofdstuk 2). Hoofdstuk 3 geeft weer welke basiskennis het museum zou kunnen aanbieden op het gebied van water. In hoofdstuk 4 wordt dieper ingegaan op trends binnen de thema's ruimte/natuur, voedsel/landbouw en klimaatverandering, waarover het museum de bezoekers kan gaan informeren. Hoofdstuk 5 laat zien hoe voor elk onderwerp een handelingsperspectief geboden kan worden, waarbij aandacht wordt besteed aan innovatie, wetenschap en de rol van het individu. In hoofdstuk 6 wordt ten slotte een procesadvies gepresenteerd.
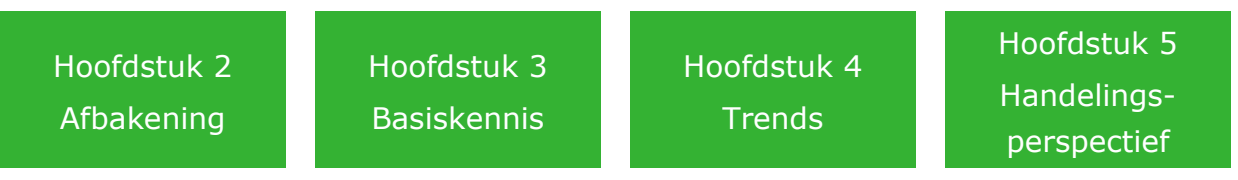

Figuur 2 Indeling hoofdstukken 


\section{Afbakening van de scope}

In dit hoofdstuk zal duidelijk worden welke keuzes geleid hebben tot de afbakening van de onderwerpen voor het museum. Eerst wordt de keuze voor een focus op zoetwater toegelicht. Vervolgens worden belangrijke maatschappelijke trends op een rij gezet. Daarna worden de verdere afbakening van de onderwerpen en de keuze voor de geografische schaal en tijd behandeld.

\section{$2.1 \quad$ Keuze voor zoetwater}

Het Nederlands Watermuseum is deel van een samenwerkingsverband tussen tien watergerelateerde musea. Om te bepalen welke onderwerpen focus krijgen in de toekomstvisie, is gekeken welke onderwerpen de andere musea al behandelen, zodat ongewenste herhaling voorkomen kan worden. In Tabel 1 staat een omschrijving van de andere negen musea en de onderwerpen die zij presenteren.

Tabel 1 Overzicht van de negen andere watergerelateerde musea in Nederland

\begin{tabular}{|c|c|c|}
\hline Museum & Korte omschrijving & Website \\
\hline $\begin{array}{l}\text { Afsluitdijk } \\
\text { Wadden Center }\end{array}$ & $\begin{array}{l}\text { Hoofdthema is overleven van de Nederlanders in de } \\
\text { Delta door de eeuwen heen en met oog op een } \\
\text { toekomst met klimaatverandering en zeespiegelstijging. }\end{array}$ & https://afsluitdijkwaddencenter.nl/ \\
\hline $\begin{array}{l}\text { Biesbosch } \\
\text { Museumeiland }\end{array}$ & $\begin{array}{l}\text { De Biesbosch is ontstaan door een enorme } \\
\text { overstroming in } 1421 \text {. De Biesbosch is zo ingericht dat } \\
\text { hij vol kan stromen om Dordrecht en Gorinchem droog } \\
\text { te houden. Het museum laat zien hoe dat gedaan wordt } \\
\text { en waarom we daar in Nederland zo goed in zijn. }\end{array}$ & http://www.biesboschmuseumeiland.nl/ \\
\hline De Cruquius & $\begin{array}{l}\text { Dit museum vertelt het verhaal van de droogmaking } \\
\text { van de Haarlemmermeer. Onderwerpen zijn de oer- } \\
\text { Hollandse strijd tegen water en de voorbereiding en } \\
\text { uitvoering van de Deltawerken van de } 19^{e} \text { eeuw. Ook } \\
\text { vinden demonstraties van de grootste stoommachine } \\
\text { ter wereld plaats. }\end{array}$ & $\begin{array}{l}\text { https://www.haarlemmermeermuseum.nl/cr } \\
\text { uquius-museum }\end{array}$ \\
\hline Het Keringhuis & $\begin{array}{l}\text { Informatiecentrum over hoogwaterbescherming in } \\
\text { Zuid-Holland en de Maeslantkering. }\end{array}$ & https://www.keringhuis.nl/ \\
\hline $\begin{array}{l}\text { Waterlinie- } \\
\text { museum }\end{array}$ & $\begin{array}{l}\text { Dit museum vertelt de geschiedenis van water in } \\
\text { Nederland en hoe van de } 17^{e} \text { tot en met de } 19^{e} \text { eeuw } \\
\text { water werd ingezet als verdediging tegen militaire } \\
\text { vijanden door middel van een waterlinie. }\end{array}$ & https://waterliniemuseum.nl/ \\
\hline $\begin{array}{l}\text { Unesco } \\
\text { Werelderfgoed } \\
\text { Woudagemaal }\end{array}$ & $\begin{array}{l}\text { Onderwerpen van dit museum zijn waterbeheer en de } \\
\text { werking van het stoomgemaal. }\end{array}$ & https://www.woudagemaal.nl/werelderfgoed \\
\hline $\begin{array}{l}\text { Watersnood } \\
\text { Museum }\end{array}$ & $\begin{array}{l}\text { Dit museum behandelt de Watersnoodramp van 1953, } \\
\text { maar ook waterveiligheid van het heden en de } \\
\text { toekomst. Met klimaatmodellen worden de effecten van } \\
\text { klimaatverandering in beeld gebracht, zoals } \\
\text { zeespiegelstijging en opwarming van de aarde. }\end{array}$ & https://watersnoodmuseum.nl/ \\
\hline
\end{tabular}


Uit Tabel 1 is af te leiden dat onderwerpen die met zoutwater, estuaria en overstromingsbescherming te maken hebben voldoende belicht worden in verschillende andere musea. Zoetwater, grote rivieren, regionale wateren en grondwater krijgen minder aandacht. Ook de relatie water-gezondheid komt in deze musea (nog) niet aan de orde. Daarbij zijn de belangrijke sponsoren, zoals het Waterschap Rijn en IJssel en de drinkwatersector, vooral gericht op zoetwater. Ten slotte maakt ook de locatie van het museum in oostelijk Nederland het logisch om op zoetwater te focussen.

\subsection{Zeven maatschappelijke trends}

Er zijn zeven belangrijke algemene trends voor de toekomst geïdentificeerd die relevant kunnen zijn voor het Watermuseum (zie Tabel 2). Voor elke trend kunnen relaties gelegd worden met zoetwater, al is dat voor de ene trend wat gemakkelijker dan voor de andere.

Tabel 2 Algemene trends die belangrijk kunnen zijn voor het Watermuseum

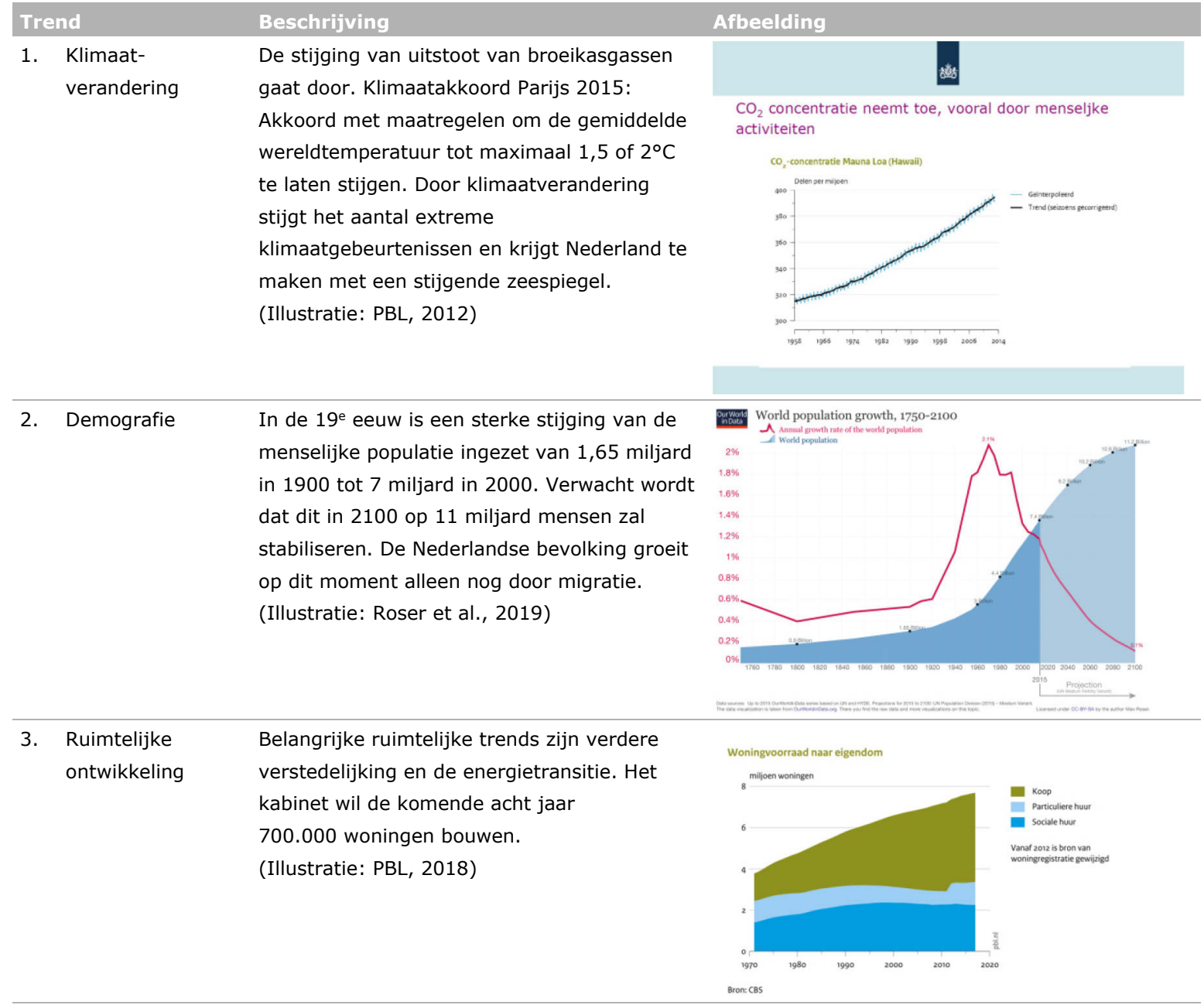

4. Landbouwtransitie
Het ministerie van Landbouw bepleit kringlooplandbouw: akkerbouw, veehouderij en tuinbouw gaan dan veel meer elkaars grondstoffen en reststromen uit de voedingsketens gebruiken. Consumenten moeten meer gaan betalen voor voedsel, want boeren verdienen te weinig en daardoor vervuilen ze het milieu. De landbouw zal vaker met droogte te maken krijgen. (Foto: Klostermann, 2018)

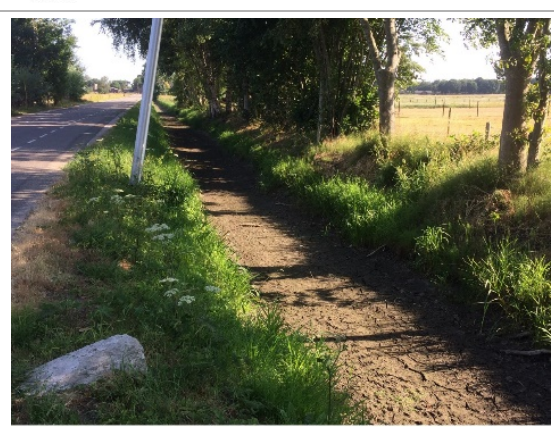




\begin{tabular}{|c|c|c|c|}
\hline \multicolumn{2}{|c|}{ Trend } & Beschrijving & Afbeelding \\
\hline
\end{tabular}

\subsection{Bepaling van de scope}

\subsubsection{Selectie van inhoudelijke domeinen}

In de eerste workshop zijn criteria vastgesteld voor de selectie van toekomstige onderwerpen voor het Watermuseum. De criteria zijn:

- Zijn er binnen de onderwerpen trends of belangrijke toekomstige ontwikkelingen waar te nemen?

- Hebben deze onderwerpen een nauwe relatie met zoetwater?

- Zijn de onderwerpen relevant voor de doelgroep?

Met deze criteria is uit de zeven trends een keuze gemaakt door de begeleidingscommissie. De geselecteerde trends zijn: ruimte gecombineerd met natuur, landbouw gecombineerd met voedsel, en klimaatverandering. Als indeling van het inhoudelijke advies is verder gekozen voor het aanbieden van basiskennis over zoetwater, het verder uitwerken van de drie geselecteerde toekomstige trends en het bieden van handelingsperspectief om negatieve trends het hoofd te bieden.

\subsubsection{Geografische schaal}

In de eerste workshop werd duidelijk dat wat betreft de geografische schaal de voorkeur ligt bij de lokale situatie dicht bij het dagelijks leven van de bezoeker. Mensen voelen zich meer verbonden met onderwerpen wanneer er sprake is van herkenning; het komt dichterbij. Wel is het belangrijk om de onderwerpen in het bredere kader van internationale ontwikkelingen te plaatsen. Sommige nationale 
ontwikkelingen kunnen niet los gezien worden van mondiale ontwikkelingen, zoals klimaatverandering. Veranderingen voor Nederland worden op deze manier in een bredere context geplaatst.

\subsubsection{Tijd}

Voor het aspect tijd is de uitkomst van de eerste workshop dat er geen harde grens gesteld wordt, zoals 2030 of 2050. Er wordt per onderwerp gekeken welke ontwikkelingen op welke tijdschaal van belang zijn. Daarnaast is er besproken dat het belangrijk is om niet in doemdenken te vervallen, aangezien kinderen de belangrijkste doelgroep zijn. 


\section{Basiskennis watersysteem}

Basiskennis over het watersysteem en de waterkringloop wordt door het Watermuseum nu al voor een deel aangeboden. In de hoofdindeling van het museum blijft het een belangrijk onderdeel, om daar de trends tegen af te zetten.

Omdat er water in vloeibare vorm op aarde is, is er leven ontstaan. Water is de bron van al het leven in de biosfeer. Wij als mens zijn volledig afhankelijk van zoetwater. Ongeveer $96 \%$ van al het water op aarde is zoutwater; dat betekent dat ongeveer $4 \%$ zoetwater is. Van die $4 \%$ is ongeveer $68 \%$ gevangen in bevroren toestand in de polen en gletsjers en $30 \%$ zit onder de grond (World Atlas, 2017).

Water is constant onderhevig aan verandering; het stroomt van de ene plek naar de andere en verandert van de ene fysieke staat naar de andere (vast, vloeibaar, gasvormig). Maar er is ook continuïteit op het gebied van water; de hoeveelheid water op aarde blijft namelijk constant. Daarnaast blijft onveranderd dat levende wezens, waaronder de mens, water nodig hebben.

In dit hoofdstuk zullen de waterkringloop en de waterketen besproken worden. Vervolgens wordt het belang van water voor de mens beschreven.

\subsection{Waterkringloop}

Met de waterkringloop wordt de constante beweging van water op, onder en boven het aardoppervlak bedoeld (World Atlas, 2017). De hoeveelheid water op aarde blijft constant, maar de vorm waarin dat water voorkomt, verandert. Door middel van verdamping, condensatie en neerslag zijn er voortdurend transities tussen de verschillende staten van water: vast, vloeibaar en gas.

De motor achter de waterkringloop is de zon. Deze kringloop is te zien in Figuur 3.

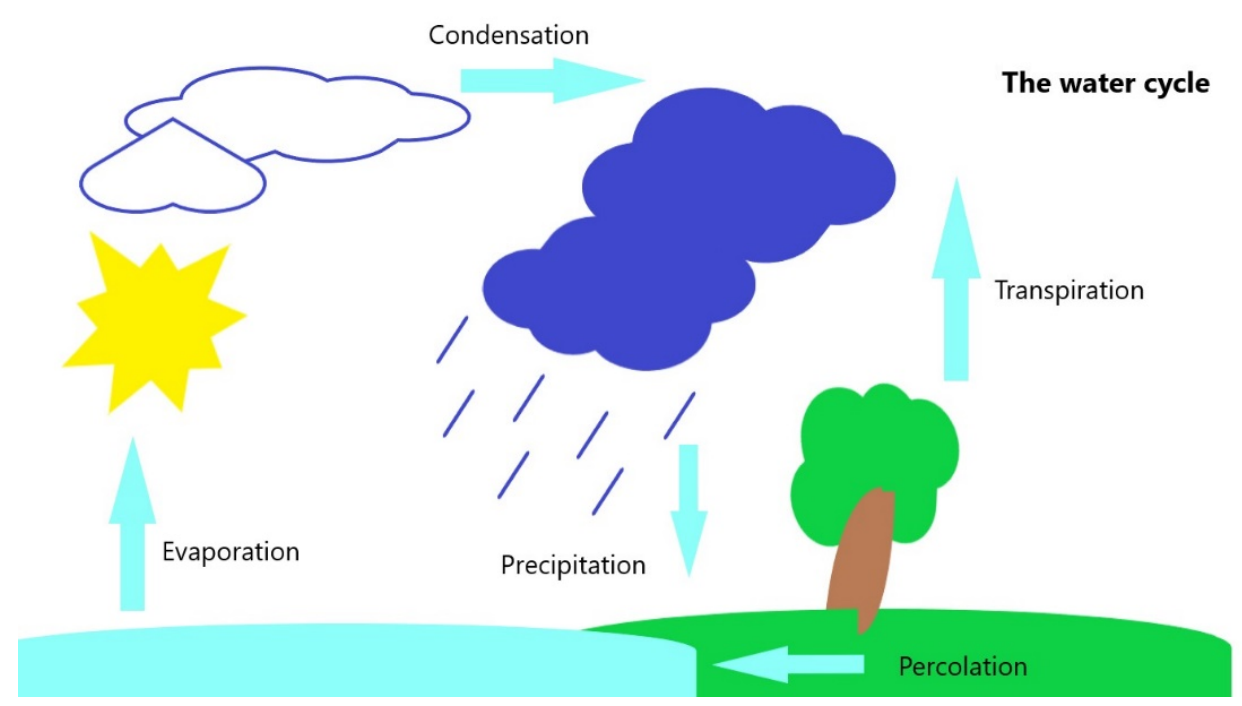

Figuur 3 De waterkringloop (Klostermann, 2020)

Water verdampt door de warmte van de zon, waarna door afkoeling via condensatie wolken worden gevormd. Als de temperatuur in en onder de wolk boven nul graden is, bestaat de wolk uit kleine waterdruppels (KNMI, 2019). Deze druppels botsen tegen elkaar en vormen zo grotere druppels, die vallen als ze te zwaar zijn geworden. Ook ijskristallen kunnen aangroeien en vallen; als ze onderweg 
smelten, worden het grote regendruppels. Zo komt het water terug op het aardoppervlak in de vorm van neerslag, zoals regen of sneeuw.

Sneeuw blijft een tijd op het aardoppervlak liggen, afhankelijk van het lokale klimaat, en kan bij opwarming in het voorjaar het begin van een rivier vormen (Burroughs, 2001). Regen komt op de aarde terecht en stroomt via de oppervlakte af naar beken en rivieren of zakt de grond in waar het zich voegt bij het grondwater. Dit grondwater verplaatst zich door verschillen in hoogte en in luchtdruk. Grondwater kan op hellingen als kwelwater omhoogkomen en het begin vormen van beken. Een ander deel van het water wordt direct opgenomen door planten, die het gebruiken en afscheiden als waterdamp. Smeltwater, oppervlakkig afstromend water en kwelwater komen in oppervlaktewateren terecht, zoals beken, meren en rivieren, waarna het terugstroomt naar de zee. Het oppervlaktewater en de zee worden opgewarmd door de zon, waarna de kringloop opnieuw begint.

\subsection{Waterketen}

De waterketen wordt gevormd door menselijke ingrepen in het watersysteem en beïnvloedt de natuurlijke waterkringloop (zie Figuur 4). Grondwater wordt opgepompt om drinkwater van te maken. In Nederland bestaat ongeveer 65\% van het drinkwater uit grondwater. De andere 35\% van het drinkwater is gezuiverd oppervlaktewater. Het drinkwater wordt gebruikt door huishoudens en industrie en wordt uiteindelijk afvalwater, dat gezuiverd wordt in een rioolwaterzuivering. Daarna komt het gezuiverde afvalwater in het oppervlaktewater terecht.

Het drinkwater werd niet altijd op deze manier gezuiverd. Tot 1920 werd er heel weinig aandacht besteed aan de bestrijding van waterverontreiniging (Berge, Groen, Havekes, Hofstra, \& Teulings, 1995). Op maar een aantal plaatsen bestond voor 1940 een rioolwaterzuiveringsinstallatie. In 1970 werd de Wet verontreiniging oppervlaktewateren van kracht. In deze tijd werd de basis gelegd voor integraal waterbeheer (Berge et al., 1995).

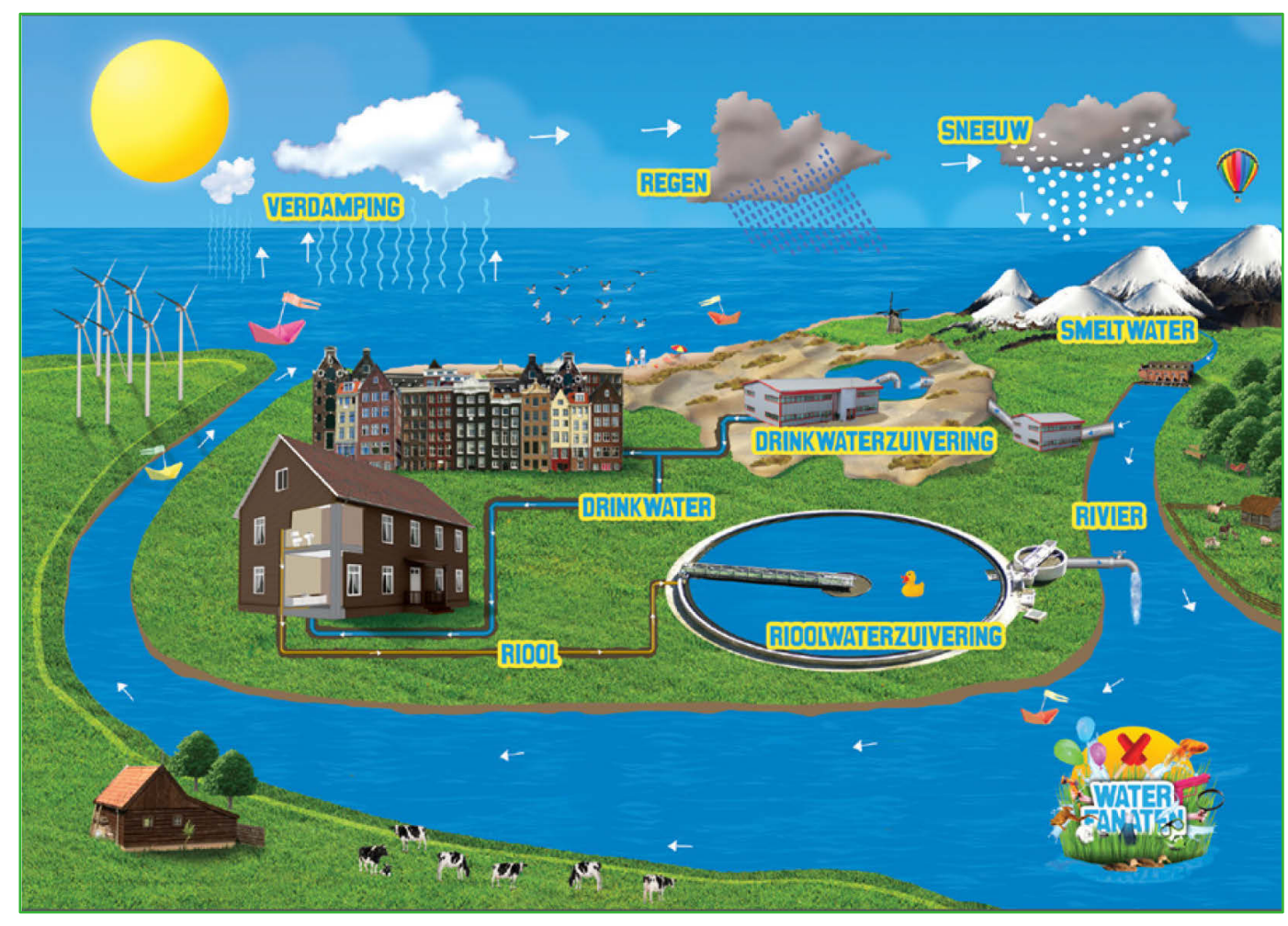

Figuur 4 Waterkringloop en waterketen (Waternet, n.d.) 


\subsection{Essentie van water voor het leven}

De eerste levensvormen zijn waarschijnlijk ontstaan in (zout)water. Althans, volgens de 'Oersoep'theorie of Abiogenese theorie (NEMO Kennislink, 2014) volgens welke in een mengsel van water, methaan, ammoniak en waterstof via elektrische ontladingen aminozuren kunnen ontstaan. Het ontstaan van leven is overigens nog grotendeels een onopgelost raadsel. Een belangrijke concurrerende theorie is dat het leven uit de ruimte op de aarde is beland. In elk geval zijn 3,5 miljard jaar oude fossielen van bacteriën gevonden als allereerste levensvorm (NEMO Kennislink, 2016).

Door evolutie hebben eencelligen zich tot meercellige waterdieren en -planten ontwikkeld, hebben organismen zich op het land gevestigd, en uiteindelijk is de mens ontstaan. Al het leven is nog steeds afhankelijk van water. Oceanen en ijskappen reguleren de temperatuur van de aarde, wat ervoor zorgt dat er leven op aarde mogelijk blijft (Lenntech, n.d.). Volgens de Gaia-hypothese vormen alle levende wezens op aarde een systeem dat als geheel probeert te overleven (Lovelock, 1979).

Elk organisme gaat anders met water om door wisselende beschikbaarheid van water in verschillende gebieden op aarde. Een grote groep planten en dieren is bij de oorsprong gebleven en leeft in het water: van plankton en waterplanten tot aan weekdieren, krab- en kreeftachtigen en gewervelde vissen. Zowel planten als dieren hebben ook het droge landoppervlak veroverd als woonplaats: eerst nog semi-afhankelijk - zoals amfibieën -, maar reptielen wonen permanent op het land. Voor alle landwezens blijft water een belangrijke levensbehoefte, al zijn sommige erg goed geworden in het omgaan met droge omstandigheden. Bepaalde cactussoorten kunnen overleven wanneer ze eens in de 2-3 maanden water krijgen. Een extreem voorbeeld is het beerdiertje: wanneer er sprake is van uitdroging, rolt het beerdiertje zich op tot een balletje en kan zo wel honderd jaar zonder water.

\subsection{Belang van water voor de mens}

De mens kan maximaal 1 week zonder water overleven (Livescience, 2012). Water reguleert veel processen in het menselijk lichaam, waaronder de bloedsomloop, de spijsvertering en de temperatuur. Via verdamping en urine raken we water kwijt dat elke dag weer aangevuld moet worden. Naast drinkwater als eerste levensbehoefte heeft de mens water nodig voor huishoudelijk gebruik, industriële processen, koelwater voor elektriciteitscentrales, bulktransport via rivieren en productie van voedsel. Van het water dat de gemiddelde Nederlander gebruikt, is 3 liter per dag nodig voor drinken en koken; 116 liter per dag voor direct gebruik in toilet, douche, voor schoonmaak etc., en daarnaast nog 6000 liter per dag voor de 'footprint' van alle producten en diensten die we gebruiken, waarvan 95\% water uit het buitenland is (The Footprint Challenge, 2017). Voor een spijkerbroek is bijvoorbeeld gemiddeld 7000 tot 8000 liter water nodig. Van dit verbruik per persoon is de eerste 3 liter een constante; alle overige hoeveelheden zijn afhankelijk van technologie en menselijk gedrag. 


\section{$4 \quad$ Toekomstige veranderingen}

In dit hoofdstuk zullen belangrijke trends binnen drie domeinen besproken worden. De drie (gecombineerde) domeinen zijn geselecteerd in een van de workshops zoals beschreven in de inleiding. Eerst zal aandacht besteed worden aan het onderwerp 'ruimte/natuur'. Vervolgens wordt er ingegaan op het onderwerp 'voedsel/landbouw', waarna trends binnen het onderwerp 'klimaatverandering' behandeld zullen worden.

Al deze onderwerpen zijn met elkaar verbonden. Natuur en landbouw hebben water en ruimte nodig. Daarnaast heeft water zelf ruimte nodig. Ten slotte beïnvloedt het klimaat de kwantiteit en kwaliteit van het water dat beschikbaar is. Bij het uitwerken van deze onderwerpen tot concrete exposities kunnen deze verbindingen een rol spelen.

\subsection{Veranderingen in ruimte en natur in Nederland}

'Goed groen begint met blauw', aldus Deltacommissaris Peter Glas (Deltanieuws, 2019). Volgens hem is het belangrijk om groen en blauw te benaderen als onlosmakelijke elementen; een integrale aanpak voor water en natuur. Deze relatie tussen waterkwaliteit en -kwantiteit en natuur wordt benadrukt in het Natuurpact, waarin afgesproken is dat naar maximale samenhang gezocht moet worden tussen natuurbeheer en de Kaderrichtlijn Water (KRW-)maatregelen (Folkert \& Boonstra, 2017).

Water is niet het enige dat belangrijk is voor natuur; er is ook ruimte nodig. Dit is een uitdaging, omdat ruimte schaars is en steden, landbouw en industriegebieden zich uitbreiden. Ook water heeft steeds meer ruimte nodig omdat piekafvoeren als gevolg van klimaatverandering vaker voor zullen komen. De competitie om bruikbaar land is een wereldwijd probleem: op meer dan 35\% van het ijsvrije land op aarde heeft natuur plaats moeten maken voor landbouw (Foley, 2009). Om de groeiende wereldpopulatie van voedsel te kunnen voorzien, zal dit percentage naar verwachting in de toekomst verder stijgen.

In Nederland is ruimte bijzonder schaars, vandaar dat ruimtelijke ordening stevig gereguleerd is. Eerst zal er ingegaan worden op het Nederlandse ruimtegebruik. Daarna wordt waterkwaliteit in verband gebracht met natuur en ten slotte zal aandacht besteed worden aan de verschuiving van soorten als gevolg van klimaatverandering.

\subsubsection{Ruimtegebruik in Nederland}

In de Nationale Omgevingsvisie (NOVI) wordt de gewenste ontwikkeling van de leefomgeving beschreven, waarin ook aandacht wordt besteed aan de toekomstbestendige ontwikkeling van het landelijk gebied (Rijksoverheid, 2018b). Hierbij moeten niet alleen de belangen van de landbouw meetellen, zoals in de ruilverkaveling, maar ook kwaliteit van het landschap, de natuur, de bodem en het watersysteem (Rijksoverheid, 2018b). Hiervoor is belangrijk dat schoon water zo lang mogelijk vastgehouden wordt. Andere focuspunten van de NOVI zijn duurzaam economisch groeipotentieel voor Nederland, ruimte voor klimaatverandering en energietransitie, ruimte voor wonen, werken en bewegen en klimaatbestendige steden (Rijksoverheid, 2018b).

In Nederland is steeds meer ruimte nodig voor verstedelijking, onder andere wonen. De populatie zal toenemen, waardoor het aantal woningen ook moet groeien. Meervoudig ruimtegebruik in de vorm van wonen op het water kan een oplossing zijn voor de toenemende vraag naar ruimte voor water en de tegelijkertijd toenemende verstedelijking (Schuwer, 2007).

Daarnaast is er een toenemende competitie tussen water voor natuurlijke ecosystemen en water voor landbouw, terwijl ook de vraag naar water vanuit steden en industrie groeit (Turral, Burke, \& Faurès, 
2011). In Nederland zelf is de drinkwatervraag gestabiliseerd sinds 1990, ondanks het feit dat de populatie in die periode is gegroeid van 15 naar 17 miljoen inwoners (Baggelaar en Geudens, 2017) (Figuur 5). Dit komt door nieuwe technologieën in huishoudens en industrie die minder water vragen.

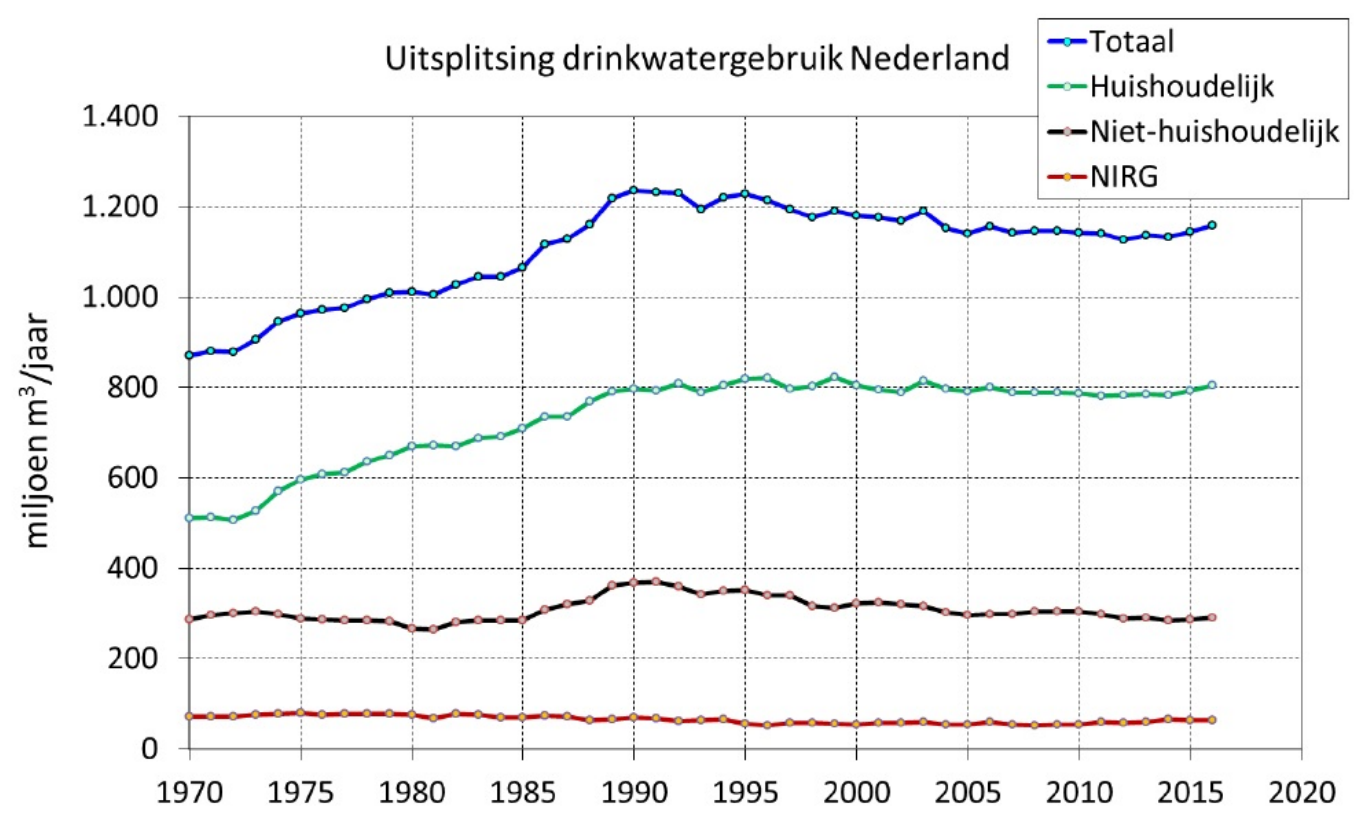

Figuur 5 Drinkwatervraag 1970-2016 (Baggelaar en Geudens, 2017). Niet-huishoudelijk gebruik is het gebruik van groot- en kleinzakelijke, agrarische en recreatieve activiteiten. NIRG is het 'niet-inrekening-gebracht'-gebruik, oftewel verliezen in het drinkwatersysteem zelf

Een succesvol voorbeeld van meer ruimte voor water is het programma Ruimte voor de Rivier. Dit programma is gestart naar aanleiding van gevaar voor overstroming tijdens de hoogwaters in 1993 en 1995 (Olde Wolbers, Das, Wiltink \& Brave, 2018). Een nieuwe visie op waterbeheer ontstond: Ruimte voor water in plaats van Water keren (Schuwer, 2007). Het programma was dan ook gericht op waterveiligheid en ruimtelijke kwaliteit (Olde Wolbers et al., 2018).

Verder lezen: Rijksoverheid. (2018) Kabinetsperspectief NOVI.

https://rijksoverheid.nl/documenten/rapporten/2018/10/05/kabinetsperspectief-novi

\subsubsection{Waterkwaliteit}

Waterkwaliteit is van groot belang voor een gezonde natuur. In 2000 is de Europese Kaderrichtlijn Water (KRW) in werking gesteld, met als doel het verbeteren van de kwaliteit van het oppervlakte- en grondwater (Van Gaalen et al., 2015). Uiterlijk in 2027 moeten de doelstellingen gehaald zijn. In veel wateren in Nederland worden de kwaliteitsdoelstellingen van de KRW nog niet gehaald; in 2015 voldeed $3 \%$ van de regionale wateren en $25 \%$ van de Rijkswateren aan alle biologische kwaliteitsdoelen (Van Gaalen et al., 2015). Belangrijke oorzaken zijn vermesting met stikstof en fosfor, versnippering van leefgebied, onnatuurlijke inrichting van wateren en belasting met bestrijdingsmiddelen. De waterkwaliteit verbetert wel, maar in 2027 zal ongeveer de helft van de wateren waarschijnlijk nog steeds niet aan de doelen voldoen (Van Gaalen et al., 2015). 
Verder lezen: Van Gaalen et al. (2015). Waterkwaliteit nu en in de toekomst. Eindrapportage ex ante evaluatie van de Nederlandse plannen voor de Kaderrichtlijn.

https://www.pbl.nl/sites/default/files/cms/publicaties/Waterkwaliteit\%20Beleidsstudie_ 4e_proef.pdf

\subsubsection{Verschuiving van soorten}

Als gevolg van klimaatverandering is een verschuiving te zien in de leefgebieden van planten- en diersoorten. Soorten hebben een bepaalde tolerantie voor minimum- en maximumtemperaturen en omdat de gemiddelde temperatuur stijgt, schuiven de grenzen van leefgebieden richting het noorden (Verweij, Van der Wiele, Van Moorselaar \& Van der Grinten, 2010). Daarnaast spelen verschillende stressfactoren voor water een rol, zoals verzuring, verzilting, eutrofiëring en versnippering van natuurgebieden. Klimaatverandering zal deze stressfactoren versterken (Verweij et al., 2010). Een voorbeeld is de verschuiving van verschillende vlindersoorten in Noord-Amerika en Europa, die in 27 jaar ongeveer 200 km naar het noorden zijn opgeschoven (Verweij et al., 2010).

Klimaatverandering betekent dat soorten met Nederland als de zuidelijke grens van hun leefgebied kunnen verdwijnen uit Nederland; soorten die Nederland als noordelijke grens van hun leefgebied hebben, kunnen juist meer in Nederland voor gaan komen (Nijhof et al. (in Verweij et al.), 2010) (zie Figuur 6). In Nederland zijn al vogelsoorten, insecten, vissen en planten die een noordelijke beweging laten zien, zoals de Heikikker en de Noordse witsnuitlibel, maar ook soorten die juist Nederland binnenkomen, zoals de Kommavlinder, de IJsvogel, de Kleine zilverreiger, de Bijenorchidee en de Vuurlibel (Verweij et al., 2010). Deze verschuivingen zullen leiden tot een andere samenstelling van flora en fauna en dat kan effect hebben op de voedselketen in de vorm van mismatches (Meijs et al., 2018). Daarnaast zal de samenstelling van bestuivende insecten veranderen, wat effect heeft op de agrarische open teelten (Meijs et al., 2018). We noemen hier veel landsoorten, maar de verschuiving vindt ook plaats in waternatuur.

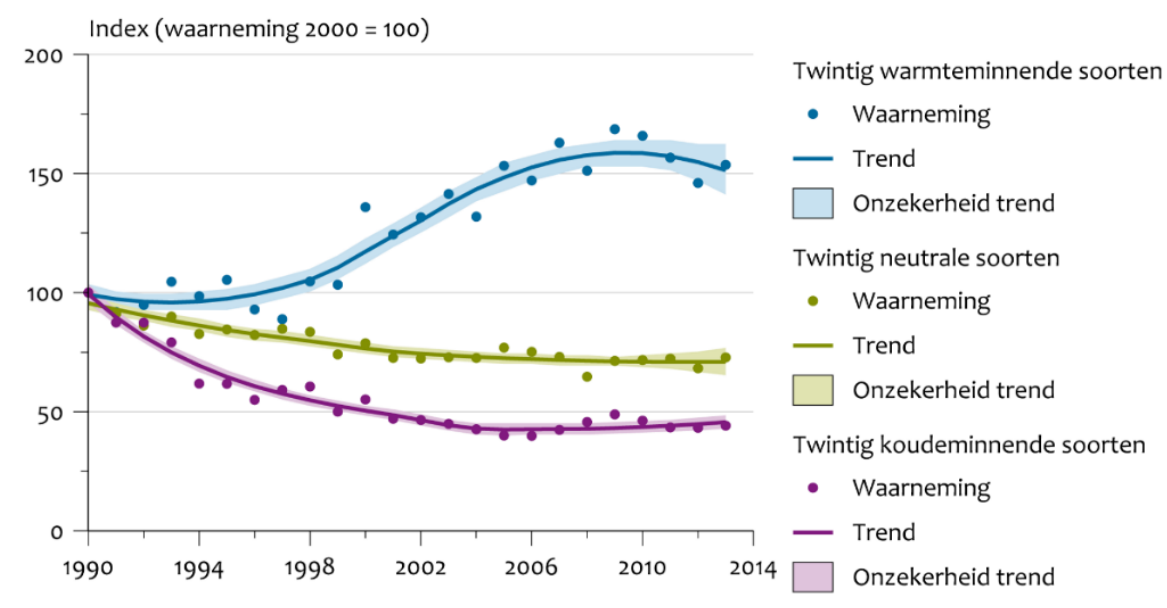

Figuur 6 Invloed klimaatverandering op soorten in Nederland (CBS, PBL, RIVM, \& WUR, 2014)

\subsubsection{Bodemdaling en veenweidegebied}

Het landoppervlak daalt in (laag-)Nederland tot wel 2 centimeter per jaar, voornamelijk door toenemende belasting van de bodem, veenafbraak en verlaging van de grondwaterstanden (Muntendam-Bos et al., 2006). Voor onze veiligheid is het belangrijk dat bodembeweging betrouwbaar gemeten kan worden. Bodembeweging heeft namelijk gevolgen voor de waterhuishouding en de stabiliteit van huizen, bruggen en dijken (NCG, 2019). Het Nederlands Centrum voor Geodesie en Geo-Informatica (NCG) heeft in samenwerking met kenniscentra, universiteiten en geodetische bedrijven een nauwkeurige interactieve bodemdalingskaart van Nederland gemaakt (zie Figuur 7). 
Deze kaart is gebaseerd op meetgegevens en maakt onderscheid tussen ondiepe en diepe oorzaken van de bodembeweging (NCG, 2019).

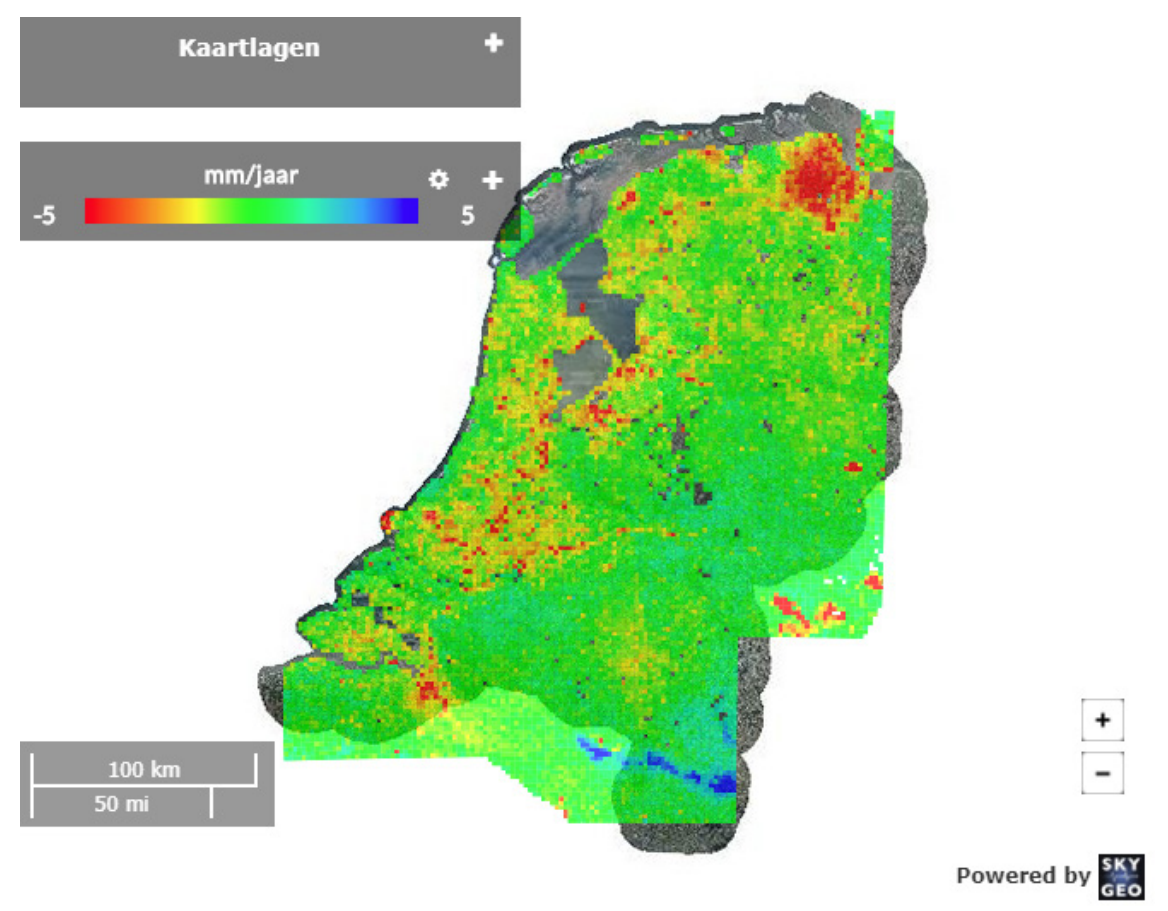

Figuur 7 Bodemdalingskaart Nederland (Bron: Bodemdalingskaart.nl, 2019)

Een belangrijk probleem in Nederland is het dalen van veenweidegebieden. Deze daling brengt problemen voor klimaat, natuur en landbouw met zich mee. Veen oxideert bij drooglegging, waardoor er per jaar 7 megaton $\mathrm{CO}_{2}$ vrijkomt: bijna $4 \%$ van de totale $\mathrm{CO}_{2}$-uitstoot van Nederland. De bodem verdwijnt dus eigenlijk in de vorm van $\mathrm{CO}_{2}$. Dit gaat het hardst in droge, warme zomers, die hoogstwaarschijnlijk in de toekomst meer voor zullen gaan komen in Nederland. Daarnaast zijn er veel bloemsoorten, insecten en vogels die het natte veenlandschap nodig hebben om te overleven.

Veenweidegebieden zijn voornamelijk in gebruik voor de melkveehouderij; een groot deel van de koeien loopt op veengrond. Deze grond is grotendeels ontwaterd, zodat de draagkracht van de bodem voldoende is voor de machines en de koeien. Als gevolg van de bodemdaling komt het maaiveld steeds dichter op het waterpeil. Als reactie hierop worden de waterpeilen eens in de tien jaar naar beneden bijgesteld. Op deze manier volgen de waterpeilen de bodemdaling. Hier ligt een van de mogelijkheden om de bodemdaling tegen te gaan; het fixeren of verhogen van het waterpeil zou hiervoor gunstig zijn en ook de biodiversiteit vooruithelpen (Bromet \& de Groot, 2019).

Verder lezen: Bromet, L., \& de Groot, T. (2019). Veen red je niet alleen; Initiatiefnota over natuur en klimaat in het veenweidegebied Retrieved from

https://groenlinks.nl/sites/groenlinks.nl/files/downloads/newsarticle/initiatiefnotaveen $\% 281 \% 29 . p d f$ 


\subsection{Voedsel/Landbouw - Europa/Nederland}

Nederland is een belangrijk exportland op het gebied van landbouw en voedsel. Het is de grootste exporteur in de EU en na de VS de tweede exporteur wereldwijd. De meeste producten worden naar Duitsland geëxporteerd; aardappelen, groente en fruit zijn de populairste producten (Rijksoverheid, 2018a). De Nederlandse landbouwsector is belangrijk voor de (inter)nationale voedselvoorziening en voor de lokale economie (Rijksoverheid, 2018b).

$\mathrm{Er}$ is een duidelijke link tussen landbouw en water; gewassen hebben water nodig om te kunnen groeien. Niet alleen voor primaire landbouwproductie, maar ook voor de productie van voedsel is water nodig. Keuzes in wat mensen eten, hebben dus effect op het watergebruik, wat uitgedrukt kan worden in de watervoetafdruk (water footprint).

Voedselsystemen maken wereldwijd veranderingen door aan zowel de vraag- als de aanbodkant. Aan de vraagkant zijn er veranderingen op het gebied van populatiegroei, consumptiepatronen, verstedelijking en inkomstenverdeling. Aan de aanbodkant spelen vooral klimaatverandering en competitie om water tussen energievoorziening, landbouw en natuur een rol (Vermeulen, Campbell, \& Ingram, 2012). Belangrijke ontwikkelingen in de Nederlandse landbouw zijn een beoogde transitie naar kringlooplandbouw en de stikstofcrisis die is ontstaan doordat de Programmatisch Aanpak Stikstof (PAS) niet legitiem bleek te zijn.

Landbouw is een van de kwetsbaarste sectoren voor klimaatverandering en water speelt in de interactie tussen klimaatverandering en landbouw een belangrijke rol (Hardelin \& Lankoski, 2015). De effecten van klimaatverandering op landbouw zullen in het hoofdstuk over klimaat behandeld worden.

In dit hoofdstuk zal er eerst ingegaan worden op het watergebruik voor landbouw en voedselproductie, waarna het nieuwe beleid voor kringlooplandbouw en de stikstofcrisis behandeld zullen worden.

\subsubsection{Watergebruik voor landbouw en voedselproductie}

Van al het water dat de Nederlander gebruikt, is $88 \%$ nodig voor de productie van ons eten en drinken, waarvan $46 \%$ voor dierlijke producten; gemiddeld $2300 \mathrm{~m}^{3}$ water per persoon per jaar (Blom et al, 2010). Hiervoor is zoetwater nodig; echter maar een klein gedeelte van het zoete water is geschikt voor consumptie. Een manier om het waterverbruik van mensen, bedrijven of landen te meten is door middel van de watervoetafdruk. Dit is een maatlat voor het menselijk waterverbruik, waarin ook watervervuiling en direct en indirect gebruik worden meegenomen (Water Footprint Network, n.d.). De mondiale watervoetafdruk in de periode van 1996 tot 2005 was 9087 miljard kubieke meter per jaar. Landbouwproductie draagt voor $92 \%$ bij aan deze totale voetafdruk (inclusief productie van katoen en rubber) (Water Footprint Network, n.d.). Dat komt niet alleen door wat er geproduceerd wordt, maar ook door op welke plek dat gebeurt. We zijn sterk afhankelijk van landbouw in gebieden met waterschaarste, terwijl er beter in waterrijke plekken geproduceerd kan worden (Hoekstra \& Prast, 2016).

\subsubsection{Kringlooplandbouw}

Minister Schouten van Landbouw, Natuur en Voedselkwaliteit heeft een nieuwe vorm van landbouw geïntroduceerd die de toekomst van de voedselvoorziening veilig moet stellen: de kringlooplandbouw. Deze nieuwe vorm van landbouw heeft als doel de uitputting van bodem, water en grondstoffen te voorkomen en de opwarming van de aarde tegen te gaan (Schouten, 2018). Volgens Schouten draagt de huidige landbouw daar niet voldoende aan bij. In plaats van verlaging van de kostprijs van producten moet er sprake zijn van verlaging van het verbruik van grondstoffen (Schouten, 2018). Resten uit de voedselketen en de agrarische sector, zoals gewasresten, procesafval, mest, voedselresten en compost, moeten in de toekomst worden hergebruikt of verwerkt tot nieuwe producten (Schouten, 2018). Op deze manier wordt de verspilling van grondstoffen beperkt. Het doel van het kabinet is kringlopen van hulpbronnen en grondstoffen in 2030 op een zo laag mogelijk schaalniveau te sluiten, zodat Nederland koploper wordt in kringlooplandbouw (Rijksoverheid, 2018b). 
Een belangrijk aspect binnen de kringlooplandbouw is een goede bodemkwaliteit. De bodemkwaliteit is ook belangrijk bij het voorkomen van schade door droogte of wateroverlast (Schouten, 2018). Op deze manier kan de link met water gelegd worden. In het realisatieplan wordt genoemd dat kringlooplandbouw zal bijdragen aan het halen van de waterkwaliteitsdoelen voor 2027 door minder gebruik van kunstmest. Daarnaast kan kringlooplandbouw bijdragen aan het veiligstellen van de drinkwatervoorziening doordat boeren zelfvoorzienend worden als ze water vasthouden, bergen en hergebruiken (Ministerie LNV, 2019). Misschien heeft kringlooplandbouw ook een positief effect op de waterkwaliteit en de stikstofdepositie.

\subsubsection{Stikstofcrisis}

In de loop van 2019 ontwikkelde zich een 'stikstofcrisis' in Nederland, met grote boerendemonstraties en alarmbellen in de bouwsector tot gevolg (NRC, 2019). Dit kan grote consequenties hebben voor de landbouwsector en dus ook voor de waterhuishouding in Nederland. Wat houdt deze crisis precies in en hoe zal dit verder gaan?

Stikstof $(\mathrm{N})$ is een element dat een belangrijke voedingsstof vormt voor plantengroei en daarom (samen met fosfaat) wordt toegediend in meststoffen. In Nederland vindt heel veel veeteelt plaats op een klein oppervlak, waarvoor het veevoer grotendeels wordt geïmporteerd. De hieruit voortkomende dierlijke mest wordt in zeer hoge toediening toegepast voor productie van o.a. mais. Dit leidt onder andere tot grote verliezen naar lucht in de vorm van ammoniak $\left(\mathrm{NH}^{3}\right)$, maar samen met fosfaat ook tot eutrofiëring van Nederlandse wateren. Door de overmaat aan mest treden ook verliezen van lachgas naar de lucht op, wat een broeikasgas is. Stikstofoxiden $\left(\mathrm{NO}_{\mathrm{x}}\right)$ worden met name uitgestoten door verkeer en industrie.

Al sinds de jaren 80 is bekend dat er te veel stikstof in natuurgebieden belandt. Indertijd heette het nog 'zure regen', wat werd veroorzaakt door depositie van zwaveldioxide $\left(\mathrm{SO}^{2}\right)$, $\mathrm{NO}_{\mathrm{x}}$ en $\mathrm{NH}^{3}$. De hoeveelheid zwavel is intussen met meer dan $80 \%$ gedaald door ingrepen in de industrie en de transportsector. Vanaf 1990 is de stikstofuitstoot ook meer dan gehalveerd, maar de afname in de uitstoot van $\mathrm{NH}^{3}$ (ammoniak) is sinds ongeveer 2010 gestagneerd. Ongeveer $40 \%$ van de stikstofdepositie is afkomstig uit de veehouderij. Op ongeveer driekwart van het Nederlandse natuuroppervlak komt nog steeds te veel stikstof terecht. Ook al daalt er door de inspanningen in industrie en landbouw minder stikstof neer, er zat al te veel in de bodem en er komt steeds meer bij. Van de 160 Natura 2000-gebieden in Nederland zijn er ongeveer 120 waarvan de stikstofdepositie boven een kritische depositiewaarde ligt.

De overheid introduceerde in 2015 het Programma Aanpak Stikstof (PAS), om de uitstoot van stikstof verder te verminderen en de negatieve gevolgen ervan te beperken, maar tegelijkertijd ruimte te bieden aan nieuwe economische activiteiten die stikstof uitstoten. In de praktijk werd het PAS gebruikt om toestemming te geven voor stikstof-uitstotende activiteiten, vooruitlopend op de positieve effecten van PAS-maatregelen om Natura 2000-gebieden te verbeteren. Vervolgens werden de stikstofuitstotende activiteiten veel voortvarender aangepakt dan de natuurbeschermende maatregelen. Het was duidelijk dat de natuur, ondanks het PAS, steeds verder achteruitging.

In mei 2019 oordeelde de Raad van State daarom dat het PAS niet voldoet. Door die 'stikstofuitspraak' kunnen in Nederland nu nauwelijks nog vergunningen worden afgegeven voor bijvoorbeeld nieuwe autowegen en woonwijken. Om dit weer vlot te trekken, gaan stemmen op om de landbouw, als grootste veroorzaker van de huidige stikstofdepositie, flink in te krimpen. In opdracht van het ministerie LNV is een adviescommissie ingesteld, het Adviescollege Stikstofproblematiek, om de minister te adviseren hoe om te gaan met de stikstofproblematiek in Nederland. Het eerste advies is 25 september 2019 verschenen in het rapport Niet alles kan - Eerste advies Adviescollege Stikstofproblematiek. Meer adviezen zullen volgen met gevolgen op de korte en de lange termijn.

Verder lezen: Wageningen Universiteit en Research - Dossier stikstof: https://www.wur.nl/nl/Dossiers/dossier/Stikstof-1.htm

Niet alles kan - Eerste advies Adviescollege Stikstofproblematiek:

https://www.rijksoverheid.nl/documenten/rapporten/2019/09/25/eerste-adviesadviescollege-stikstofproblematiek 


\subsection{Klimaatverandering - mondiaal}

De veranderingen in ons klimaat zijn niet meer te ontkennen; er is een duidelijke stijgende trend in temperatuur, zeespiegelstijging en de concentratie van $\mathrm{CO}_{2}$ in de atmosfeer (IPCC, 2014). Het IPCC (2014) laat met Figuur 8 twee mogelijke scenario's zien wat betreft de stijgende trend in temperatuur. Het negatiefste scenario schat een toename in van de gemiddelde temperatuur (ten opzichte van het gemiddelde van de periode 1850-1900) van 3,5 tot 6 graden. Deze gemiddelden kunnen voor bepaalde regio's nog veel grotere temperatuurstijgingen betekenen. Dit zijn resultaten uit het IPCCklimaatrapport uit 2014; er wordt nu hard gewerkt aan een nieuw rapport, dat uit zal komen in 2021.

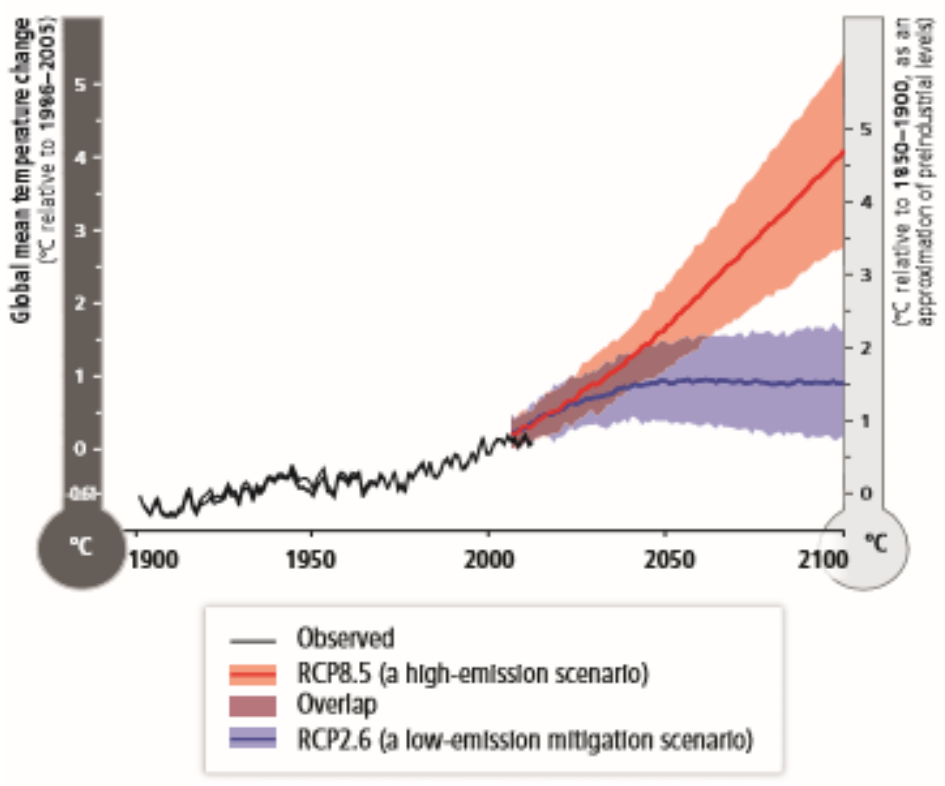

Figuur 8 Mondiale gemiddelde temperaturstijging ten opzichte van de periode 1850-1900 (IPCC, 2014)

Klimaatverandering heeft effect op vele aspecten, waaronder intensiteit en frequentie van regen, watertemperatuur en waterkwaliteit, en frequentie van extremen (droogte, overstromingen) (Javeline, Dolšak, \& Prakash, 2019). Water heeft een bijzondere rol in klimaatverandering, omdat de vele terugkoppelingen in de hydrologische kringloop verschillende effecten van de opwarming van de aarde versterken (Morgan, 2018). Een voorbeeld hiervan is het smelten van gletsjers en het landijs van Groenland en Antarctica, een van de sterkste indicatoren van klimaatverandering (Turral et al., 2011). Het effect van smeltend landijs op Groenland en Antarctica en het verdwijnen van ijs in de Arctische oceaan is tweeledig: ten eerste stijgt hierdoor de zeespiegel en ten tweede daalt hierdoor het weerkaatsingsvermogen van de aarde. Dit zorgt voor een verdere opwarming van de atmosfeer. In de volgende paragrafen zullen de verschillende effecten van klimaat in relatie tot water aan bod komen.

\subsubsection{Waterkwantiteit}

Verandering in neerslagpatronen en het smelten van sneeuw en ijs hebben in verschillende regio's effect op het hydrologische systeem, met veranderingen in de beschikbaarheid van water als resultaat (IPCC, 2014). Naast klimaatverandering hebben populatiegroei, landbouwproductie en economische ontwikkeling effect op de beschikbaarheid van water (Bijl et al., 2018). Er zijn dus veel aspecten van invloed, wat onzekerheid over de toekomst met zich meebrengt. Over het algemeen kan gezegd worden dat de gebieden die al waterschaarste kennen, nog warmer en droger zullen worden (Turral et al., 2011). Ook zal de neerslag variabeler zijn en is een effect merkbaar op gletsjerrivieren als die veranderen in regenrivieren met een minder constante waterafvoer. Regenval zal toenemen in de tropische gebieden en in de gebieden met een hogere breedtegraad, terwijl de gebieden met een 
gematigde breedtegraad, semi-aride gebieden en de binnenlanden van grote continenten een vermindering in neerslag zullen ervaren (Turral et al., 2011). Dat betekent dat problemen die al bestaan op het gebied van droogte of overstromingen waarschijnlijk zullen verergeren. Deze problemen zullen ook meer impact hebben door de voortgaande populatiegroei (Turral et al., 2011).

\subsubsection{Waterkwaliteit}

De effecten van klimaatverandering op waterkwaliteit zijn lastig te beoordelen en erg onzeker (Hardelin \& Lankoski, 2015). Een toename in droogte kan leiden tot stijgende concentraties van vervuilende stoffen in waterlichamen en/of verzilting van kustgebieden als gevolg van de zeespiegelstijging (Hardelin \& Lankoski, 2015). Meer en hevigere regenval kan zorgen voor een toename in afvloeiing van water en overstromingen. Dit kan een toename in vervuiling betekenen, omdat de overstromingen sediment, stikstof van landbouw, ziekteverwekkers en pesticiden met zich mee kunnen nemen, wat weer kan leiden tot eutrofiëring van benedenstroomse wateren (Union of Concerned Scientists, n.d.). Dit maakt het water troebeler en vormt een gevaar voor waterplanten en -dieren (Verweij et al., 2010). Daarnaast zal door de stijgende luchttemperatuur de watertemperatuur over het algemeen toenemen in rivieren en meren, wat leidt tot een afname van het zuurstofgehalte, dat een negatief effect heeft op aquatische soorten die afhankelijk zijn van zuurstof (Union of Concerned Scientists, n.d.). Andere gevolgen van een stijgende watertemperatuur zijn versnelde biochemische processen en veranderingen in stratificatiepatronen (Verweij et al., 2010).

\subsubsection{Extremen}

$\mathrm{Er}$ is een duidelijke toename te zien in de frequentie van klimaatextremen, Het aantal hittegolven, droogteperioden, stormen en natuurbranden is wereldwijd verdubbeld sinds 1980, en het aantal overstromingen is zelfs vier keer zo hoog als in 1980 (European Commission, 2018). Het is waarschijnlijk dat zware neerslag zal toenemen in de komende eeuw. Wel zijn er veel verschillen tussen regio's en zijn er ook gebieden die een afname laten zien (KNMI, 2012). Het is in ieder geval duidelijk dat neerslag variabeler gaat worden, met een hogere frequentie van droogte en overstromingen als gevolg (Turral et al., 2011). Hoeveel schade dit soort extremen zullen veroorzaken is sterk afhankelijk van kwetsbaarheid en mate van blootstelling van ecosystemen en sociale systemen (IPCC, 2014). Effecten zijn verstoring van voedselproductie en watertoevoer, schade aan infrastructuur en huizen en het verlies van levens (IPCC, 2014).

\subsubsection{Zeespiegelstijging}

Het is waarschijnlijk dat hoge waterstanden van de zee als gevolg van klimaatverandering vaker zijn voorgekomen in de geschiedenis van de planeet en het is zeer waarschijnlijk dat de zeespiegelstijging in deze eeuw zal doorzetten (KNMI, 2012). Daarnaast is het zeer waarschijnlijk dat kustgebieden en laaggelegen gebieden door deze stijging van de zeespiegel te maken krijgen met overstromingen en erosie (IPCC, 2014). De stijging heeft ook effect op de beschikbaarheid van zoetwater in kustgebieden, door het gevaar van verzilting. Onder alle IPCC-scenario's zal de zeespiegelstijging hoogstwaarschijnlijk de $2.0 \mathrm{~mm} /$ jaar overschrijden door de opwarming van het zeewater en het smelten van gletsjers en landijs (Klein Tank, Beersma, Bessembinder, Van den Hurk \& Lenderink, 2015). Zelfs wanneer de klimaatafspraken uit Parijs worden nagekomen, kan de stijging van de zeespiegel nog 1 en mogelijk 2 meter bedragen in 2100 (Deltaprogramma, 2019). Factoren die van invloed zijn op de variatie in de stijging van de zeespiegel zijn veranderingen in volume door veranderingen in temperatuur en zoutgehalte en het feit dat smeltwater van landijs niet gelijk verdeeld wordt over de oceanen (Klein Tank et al., 2015). De toename in populatie, economische ontwikkeling en verstedelijking vergroten de kwetsbaarheid van de mens voor de effecten van de zeespiegelstijging (IPCC, 2014).

Verder lezen: Deltaprogramma. (2019). Voortgang van het Deltaprogramma op hoofdlijnen. Retrieved from https://deltaprogramma2019.deltacommissaris.nl/2.html 


\subsubsection{Effecten klimaatverandering op landbouw - mondiaal}

De landbouw is sterk afhankelijk van het weer. Het weer verandert onder invloed van klimaatverandering; de stijgende temperatuur in de atmosfeer zal wereldwijd leiden tot een hogere waterbehoefte van gewassen (Turral et al., 2011). Over het algemeen zal het bodemvocht toenemen in Noord- en Oost-Europa onder 2 graden opwarming, maar dit kan regionaal sterk verschillen (European Commission, 2018). Studies in verschillende gebieden en naar verschillende soorten gewassen hebben laten zien dat klimaatverandering meer negatieve dan positieve effecten zal hebben op de opbrengst van gewassen (IPCC, 2014) (zie Figuur 9). Positieve effecten zijn vooral te vinden in noordelijke gebieden, waar het groeiseizoen verlengd zal worden (Turral et al., 2011). Wereldwijd heeft klimaatverandering een negatief effect op de opbrengst van mais en graan (IPCC, 2014). Dat komt door een combinatie van meer variatie in neerslag, verminderde waterbeschikbaarheid en een hogere waterbehoefte van gewassen (Turral et al., 2011). Landbouw ondervindt dus de gevolgen van klimaatverandering, maar draagt er op hetzelfde moment ook aan bij door de uitstoot van broeikasgassen. Bedrijven en organisaties in de landbouwsector hebben in het kader van het Klimaatakkoord als doel om deze uitstoot met 3,5 megaton $\mathrm{CO}_{2}$-equivalenten te verminderen in 2030 (Schouten, 2018).

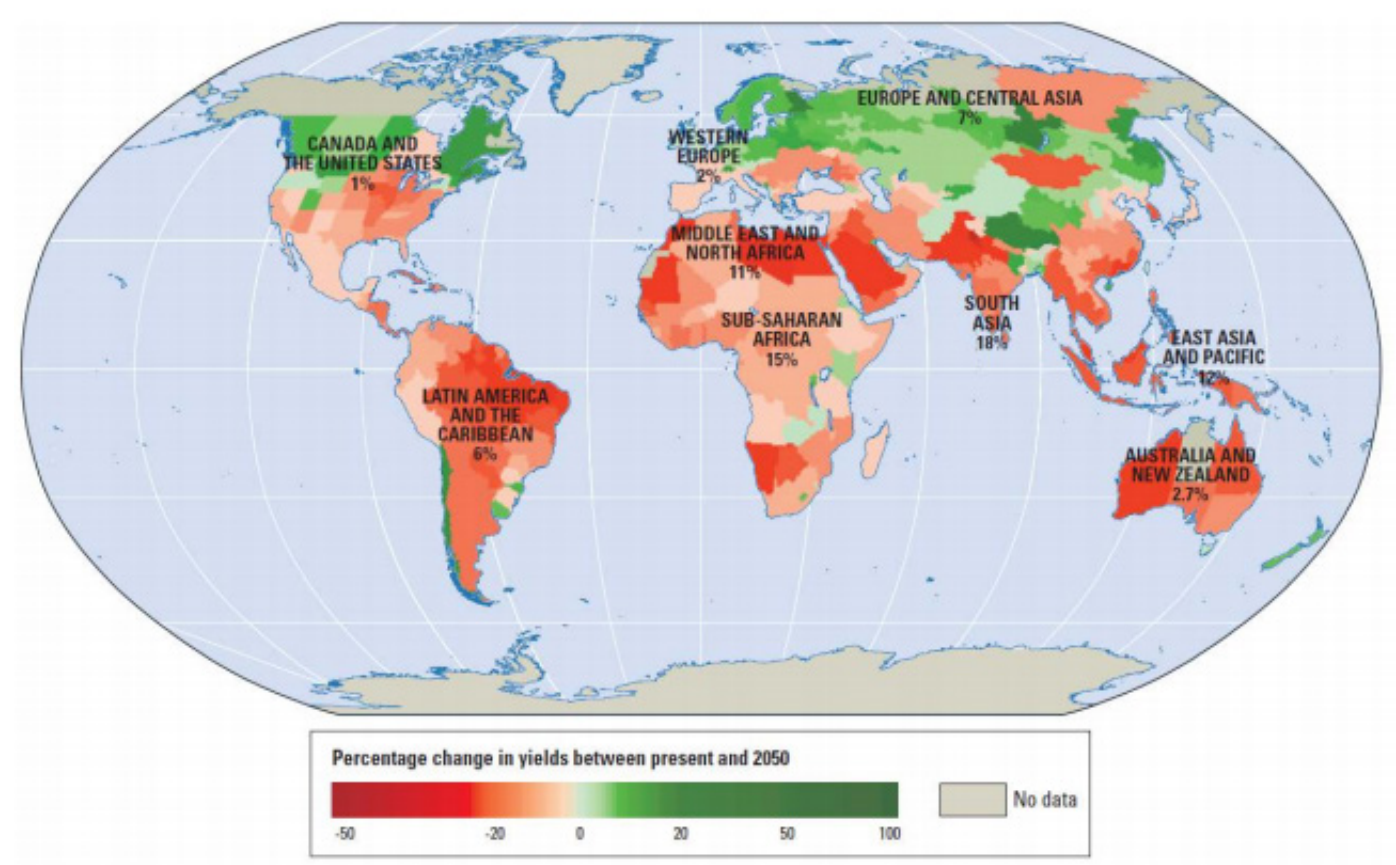

Figuur 9 Invloed van klimaatverandering op landbouw in 2050 (World Bank, 2009)

\subsubsection{Effecten klimaatverandering op landbouw - Europa}

De opbrengst van irrigatiegewassen neemt over het algemeen af in Europa, omdat het groeiseizoen korter wordt in droge, zuidelijke gebieden (European Commission, 2018). De efficiëntie van fotosynthese in planten komt tot een bepaald optimum als de temperatuur stijgt (afhankelijk van soort gewas). Nadat dat optimum bereikt is, nemen de fotosynthese en dus de productiviteit af, terwijl de respiratie blijft toenemen, waardoor de plant uiteindelijk doodgaat. Dat betekent dat als alle andere factoren stabiel blijven, de productiviteit van planten afneemt als de temperatuur langdurig boven het optimum blijft (Turral et al., 2011). Tegelijkertijd zal de vraag naar gewassen toenemen door de toenemende wereldbevolking (IPCC, 2014). De verwachting is dat de mondiale vraag naar voedsel met ongeveer $70 \%$ zal toenemen in 2050 , en zelfs een verdubbeling zal laten zien in ontwikkelingslanden (Turral et al., 2011). Zonder klimaatverandering zou dit neerkomen op een toename in het watergebruik van irrigatie landbouw van $11 \%$ (Turral et al., 2011). 


\subsection{Klimaatverandering - Nederland}

Water, en de afwezigheid daarvan, is de voornaamste manier waarop mensen het klimaat en daardoor ook klimaatverandering, ervaren (Morgan, 2018). Dat gebeurt op verschillende manieren: een tekort of een overvloed aan water kan rampen veroorzaken op de korte termijn, terwijl een langzame verandering van de zeespiegel een indicatie kan zijn voor klimaatverandering op de lange termijn (Morgan, 2018). Er zijn dus belangrijke gevolgen van klimaatverandering die met water te maken hebben. Tegelijkertijd is waterdamp een belangrijk broeikasgas dat bijdraagt aan de opwarming van de aarde.

In Nederland zijn veranderende weerpatronen te verwachten met droogte en overstromingen tot gevolg. Nederland is een waterrijk land en het grootste deel van het land ligt onder zeeniveau. Het water kan meestal onder controle gehouden worden. Door klimaatverandering kan de veerkracht van Nederland ten opzichte van waterextremen verminderen (Verweij et al., 2010). Dit vraagt om waterbeheer dat vooruitkijkt naar mogelijke problemen in de toekomst. Naast hoogwaterbescherming zijn er andere watergerelateerde uitdagingen in Nederland: waterberging, het voorkomen van verdroging en het verbeteren van de waterkwaliteit (Smit, Oosterhuis, Van Kreveld, \& Braakhekke, 2014). In dit hoofdstuk zal aandacht besteed worden aan waterkwantiteit, waterkwaliteit, extremen en zeespiegelstijging in combinatie met bodemdaling.

\subsubsection{Waterkwantiteit}

Het KNMI heeft vier verschillende klimaatscenario's voor Nederland ontwikkeld op basis van de bevindingen van het IPCC (2014) en berekeningen met klimaatmodellen voor Europa (Klein Tank et al., 2015). De scenario's laten rond 2050 een temperatuurstijging zien van $0,9^{\circ} \mathrm{C}$ tot $2,3^{\circ} \mathrm{C}$ in de winter en $0,9^{\circ} \mathrm{C}$ tot $2,8^{\circ} \mathrm{C}$ in de zomer (Klein Tank et al., 2015). Vergeleken met de mondiale temperatuurstijging stijgt de temperatuur in Nederland twee keer zo snel, wat voornamelijk komt door westenwinden in de winter en een stijging in zonnestraling in de zomer (Verweij et al., 2010). Deze stijging heeft grote gevolgen voor water in Nederland. De temperatuur versnelt de waterkringloop; water verdampt sneller, waardoor de kans op droogte groter wordt. De waterdamp in de atmosfeer is significant gestegen sinds 1950 (Klein Tank et al., 2015). Ook een toename in droogte is geregistreerd in Nederland sinds 1951 en het is waarschijnlijk dat deze trend doorzet in de toekomst (Klein Tank et al., 2015). Nederland kent weliswaar een toename van de jaarlijkse neerslag met 26\% tussen 1910 en 2013, maar de verdeling van de neerslag verschuift; alle seizoenen zijn natter geworden, behalve de zomer (Klein Tank et al., 2015).

De zomer van 2018 is een voorbeeld van een periode waarin droogte is opgetreden. Deze zomer valt onder de 5\% droogste zomers sinds 1906 (Haastregt, 2018). De droogte heeft tot problemen geleid in de landbouw, industrie en elektriciteitscentrales. De scheepvaart kwam in de problemen door de extreem lage waterstanden; daarom wordt internationale afstemming over de minimale afvoer van de Rijn steeds belangrijker (Vonk, Bouwman, Van Dorland \& Eerens, 2015). Een groot deel van de afvoer van de Rijn bestaat uit smeltwater uit de Alpen. Een toename van temperatuur in de Alpen leidt tot een afname van de watervoorraad in gletsjers en een toename van de kans op zomerlaagwater (De Wit, Buiteveld, Van Deursen, Keller \& Bessembinder, 2008). De waterstanden zullen afhankelijker zijn van neerslag, wat een grotere mate van variabiliteit met zich meebrengt (van een gletsjerrivier naar een regenrivier).

Naast het gevaar van droogte zal er ook een groter risico zijn op overstromingen; extreme neerslag in de winter zal toenemen in Nederland (Klein Tank et al., 2015). De toename in extreme neerslag verhoogt de kans op hoge rivierafvoeren en overstromingsrisico van de Rijn en Maas en kleinere rivieren (Klein Tank et al., 2015). Wanneer het gaat over overstromingen in Nederland moeten we ook buiten de grenzen kijken. Een dijkdoorbraak in Duitsland of België kan bijvoorbeeld ook zorgen voor een overstroming in Nederland (Vonk et al., 2015). Extreme regenval in een van deze landen kan leiden tot hoge piekafvoeren in Nederland. 
Verder lezen: Klein Tank, A., Beersma, J., Bessembinder, J., van den Hurk, B., \& Lenderink, G. (2015). KNMI'14 Climate scenarios for the Netherlands. Retrieved from http://www.klimaatscenarios.nl/brochures/images/Brochure_KNMI14_EN_2015.pdf

\subsubsection{Waterkwaliteit}

De verwachting is dat klimaatverandering op het gebied van waterkwaliteit geen nieuwe problemen zal veroorzaken, maar dat bestaande problemen zullen verergeren (Verweij et al., 2010). Door temperatuurstijging zal de kwaliteit van het water slechter worden; de concentratie van zuurstof zal verminderen en er zal meer eutrofiëring optreden (Verweij et al., 2010). De watertemperatuur zal met de luchttemperatuur toenemen; voor de Rijn betekent dit dat tot 2050 het aantal dagen waarop de temperatuur hoger is dan 25 graden zal toenemen; bij lage afvoeren kan er sprake zijn van een verdubbeling (Vonk et al., 2015). Dit heeft effect op het overleven van waterorganismen. Door de stijging van de temperatuur is de verwachting dat waterrecreatie zal toenemen, wat echter ingeperkt kan worden door blauwalg in recreatiewater (Verweij et al., 2010). De kwaliteit van het water in West-Nederland kan ook bedreigd worden door zoutwater dat de kuststrook binnendringt door de stijging van de zeespiegel en door zoute kwel (Oude Essink, Van Baaren, \& De Louw, 2010).

\subsubsection{Extremen}

In de toekomst zullen hittegolven vaker voorkomen en koudegolven afnemen (KNMI, 2018). Daarbij warmen de koudste dagen in het jaar sneller op dan andere dagen, doordat we in Nederland vaker westenwind zullen hebben in de winter en als de wind uit het noordoosten komt, is deze niet meer zo koud als vroeger (KNMI, 2018). Extremen op het gebied van regen zullen vaker voorkomen, zowel in de winter als in de zomer (KNMI, 2018). De trend is het sterkst voor hevige onweersbuien in de zomer, waarbij bliksem, hagel en windvlagen extremer worden (KNMI, 2018). Er zijn echter niet genoeg metingen om dit op basis van waarnemingen vast te stellen (KNMI, 2018). Weersextremen op andere plaatsen ter wereld kunnen ook risico's voor Nederland met zich meebrengen, wanneer er handelsrelaties bestaan met die plaatsen (Vonk et al., 2015). Daardoor zouden grondstoffen of halfproducten duurder of beperkt(er) beschikbaar kunnen worden voor Nederlandse bedrijven.

\subsubsection{Zeespiegelstijging}

Bijna een derde van Nederland ligt onder zeeniveau en de bodem daalt (zie Figuur 10; zie ook paragraaf 4.1.4). De kans is groot dat meer zeewater in het Nederlandse watersysteem zal binnendringen (Oude Essink et al., 2010). Wanneer de zeespiegel met 1 tot 2 meter stijgt in 2100, kunnen we in Nederland rond 2050 te maken krijgen met een afname van het oppervlak van intergetijdengebieden in de Westerschelde, Oosterschelde, Waddenzee en het benedenrivierengebied (Deltaprogramma, 2019). Ook wordt het afvoeren van water uit bijvoorbeeld het IJsselmeer naar de zee moeilijker, omdat het minder lang onder vrij verval geloosd kan worden. Wanneer hoogwater door een storm op zee voorkomt in combinatie met hogere rivierafvoeren, kan de situatie zich voordoen dat er geen afvoer mogelijk is. Lagere rivierafvoeren in de zomer kunnen juist leiden tot verzilting van oppervlakte- en grondwater (Kwadijk et al., 2010). 


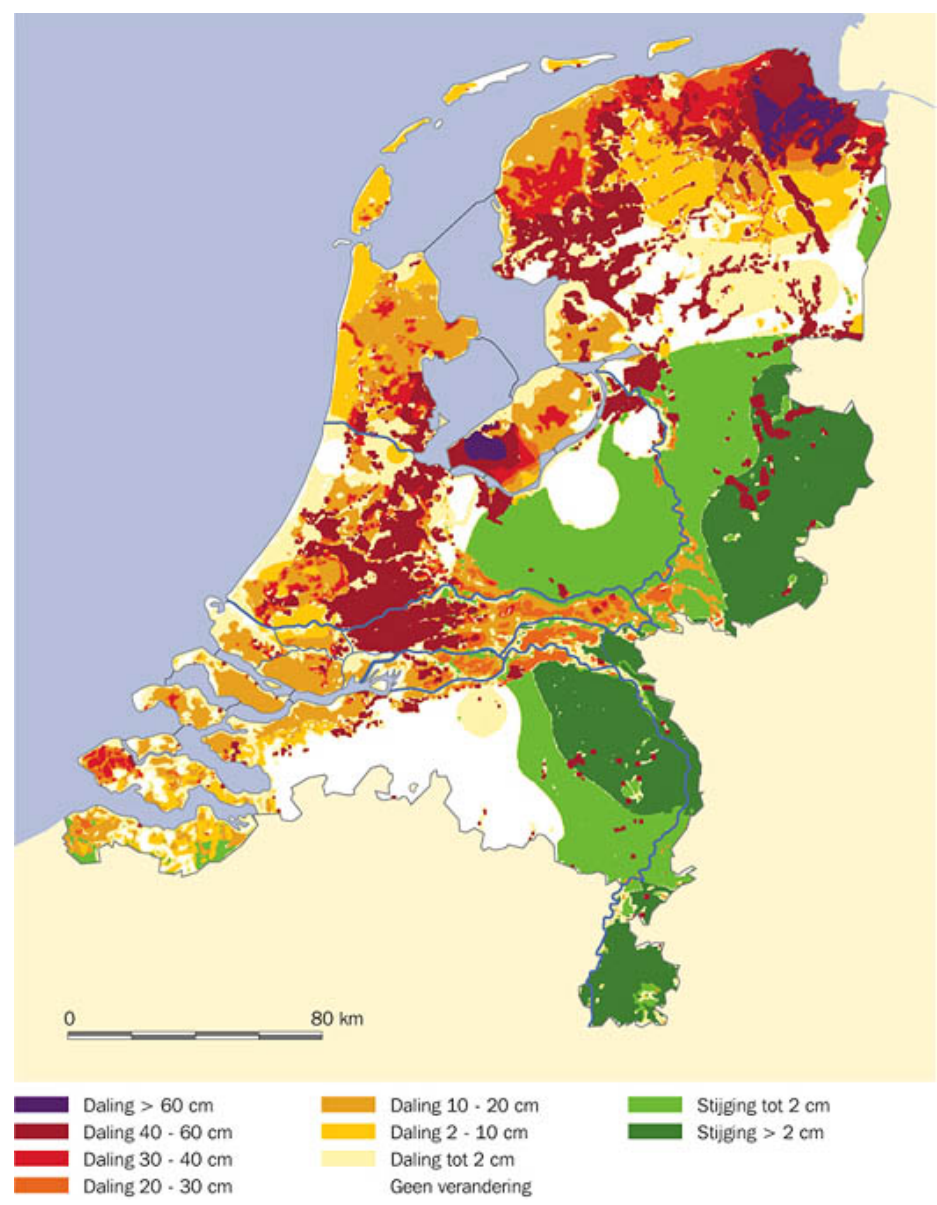

Figuur 8 Verwachte maaivelddaling in 2050 (Muntendam-Bos, Kroon, Fokker \& Lange, TNO Geologische Dienst Nederland, 2006) 


\section{$5 \quad$ Handelingsperspectief}

In dit hoofdstuk zal door een combinatie van mogelijke eigen acties, innovaties en wetenschap een handelingsperspectief worden beschreven voor de genoemde problemen/uitdagingen binnen de drie onderwerpen ruimte/natuur, voedsel/landbouw en klimaat.

\section{$5.1 \quad$ Ruimte/natur}

Voor de trends in ruimte en natuur zijn verschillende handelingsperspectieven. In dit hoofdstuk wordt aandacht besteed aan oplossingen voor de daling van het veenweidegebied, voor natuurinrichting en -herstel en voor het 'vergroenen' van de leefomgeving.

\subsubsection{Vernatting van veengebieden}

Er zijn drie soorten maatregelen mogelijk voor de vernatting van het veenweidegebied: peilfixatie, onderwaterdrainage en alternatief landgebruik. Normaal gesproken wordt in veengebieden het grondwaterpeil door waterschappen 'geïndexeerd': het peil volgt de bodemdaling en wordt bijvoorbeeld elke 3 jaar $2 \mathrm{~cm}$ naar beneden bijgesteld. Peilfixatie houdt in dat het peil niet meer geïndexeerd wordt, maar dat het peil op een vast niveau gehouden wordt, met vernatting van graslanden als gevolg. Technisch is dit een relatief eenvoudige maatregel en het zorgt voor een vermindering van de $\mathrm{CO}_{2}$-uitstoot. Wel maakt dit de veengebieden minder geschikt voor melkveehouderij.

Bij de tweede maatregel, onderwaterdrainage, wordt een drainagesysteem aangelegd waarmee water uit de sloten de veenweiden in kan lopen, waardoor bodemdaling wordt gehalveerd en oxidatie wordt beperkt. Ongeveer $40 \%$ van de ontwaterde veengebieden in Nederland is geschikt voor deze maatregel. Voordeel is dat melkveehouderij mogelijk blijft. Echter de kosten zijn hoger dan bij peilfixatie en de grond blijft te droog voor volledig veenbehoud.

Ten slotte is alternatief landgebruik een optie, zoals een transitie naar natuur waar extensieve landbouw mogelijk blijft. Hierbij is het nadeel dat de economische opbrengsten van de landbouw grotendeels verdwijnen en bovendien is dit praktisch zeer uitdagend om door te voeren. Er zijn wel opties om natte landbouw te gaan bedrijven, bijvoorbeeld de teelt van wilde rijst, cranberries en lisdodden. Dit biedt een oplossing voor bodemdaling, oxidatie en verzilting en er kan een rijke biodiversiteit ontstaan. Een dergelijke transitie zal jaren duren en leidt tot een ingrijpende verandering van het landschap (Bromet \& De Groot, 2019).

\subsubsection{Inrichting en herstel natuur}

Om de effecten van klimaatverandering te kunnen incasseren, is het belangrijk dat de natuur robuust is ingericht (Meijs et al., 2018). Er is meer ruimte nodig voor de natuur; iets wat schaars is in Nederland. Er liggen kansen voor ruimtelijke ontwikkeling in gebieden waar de aanwezige sectoren of bedrijven in de toekomst niet meer rendabel kunnen werken, zoals landbouw, industrie en grondstoffenwinning (Smit et al., 2014).

Een tweede oplossingsrichting om met de veranderingen in Nederland om te gaan, is het werken met klimaatbuffers. Klimaatbuffers zijn gebieden waarin klimaatadaptatiedoelstellingen samengaan met natuurdoelstellingen (Smit et al., 2014). De doelstellingen gericht op klimaatadaptatie zijn dan bijvoorbeeld waterveiligheid, waterberging en watervoorziening. In deze buffers worden natuurlijke processen ingezet, zoals brede vooroevers ter bescherming van dijken en herstel van de sponswerking van natuur om verdroging tegen te gaan. 
In het Deltaplan Biodiversiteitsherstel wordt een plan gepresenteerd om biodiversiteitsverlies te stoppen en om de variëteit aan ecosystemen, soorten en landschappen te herstellen. Dit is van belang voor een robuuste natuur, maar vormt ook de basis van onze welvaart en ons welzijn (Netherlands Ecological Research Network, 2018). Een gezonde bodem en voldoende insecten vormen de basis voor een toekomstbestendige voedselproductie (Netherlands Ecological Research Network, 2018).

Om natuurgebieden te beschermen, uit te breiden en te versterken, is het Natuurnetwerk Nederland opgericht. Hierbij is het verbeteren van de milieu- en watercondities ook een doel (Folkert \& Boonstra, 2017). Afspraken over het realiseren van het natuurnetwerk zijn vastgelegd in het Natuurpact: provincies moeten per 2027 minimaal 80.000 extra hectare grond natuur realiseren en de provincies zijn goed op weg om dit te halen (Interprovinciaal Overleg, 2017). Wel zijn er verschillen: de noordelijke provincies groeien minder snel qua natuur, terwijl de zuidelijke provincies juist een inhaalslag gemaakt hebben. Helaas zijn de milieucondities in zeker $40 \%$ van het Natuurnetwerk Nederland slecht; in 45\% zijn de condities matig tot slecht (Interprovinciaal Overleg, 2017). Dit betekent dat de gebieden te klein of te geïsoleerd zijn om soorten ruimte te bieden om te overleven.

Marker Wadden

De Marker Wadden is een project in het Markermeer waarbij een groep natuureilanden aangelegd wordt met zand, slib en klei uit het Markermeer. De functie van deze eilanden is tweeledig. Enerzijds lost het deels het slibprobleem van het Markermeer op; een dikke laag slib op de bodem is een probleem voor de flora en fauna in het gebied. Anderzijds hebben de eilanden als functie om nieuw leefgebied te vormen voor vissen en vogels, zowel onder als boven water (zie Figuur 11). De eilanden zullen deels ook toegankelijk zijn voor recreatie (Natuurmonumenten, n.d.).

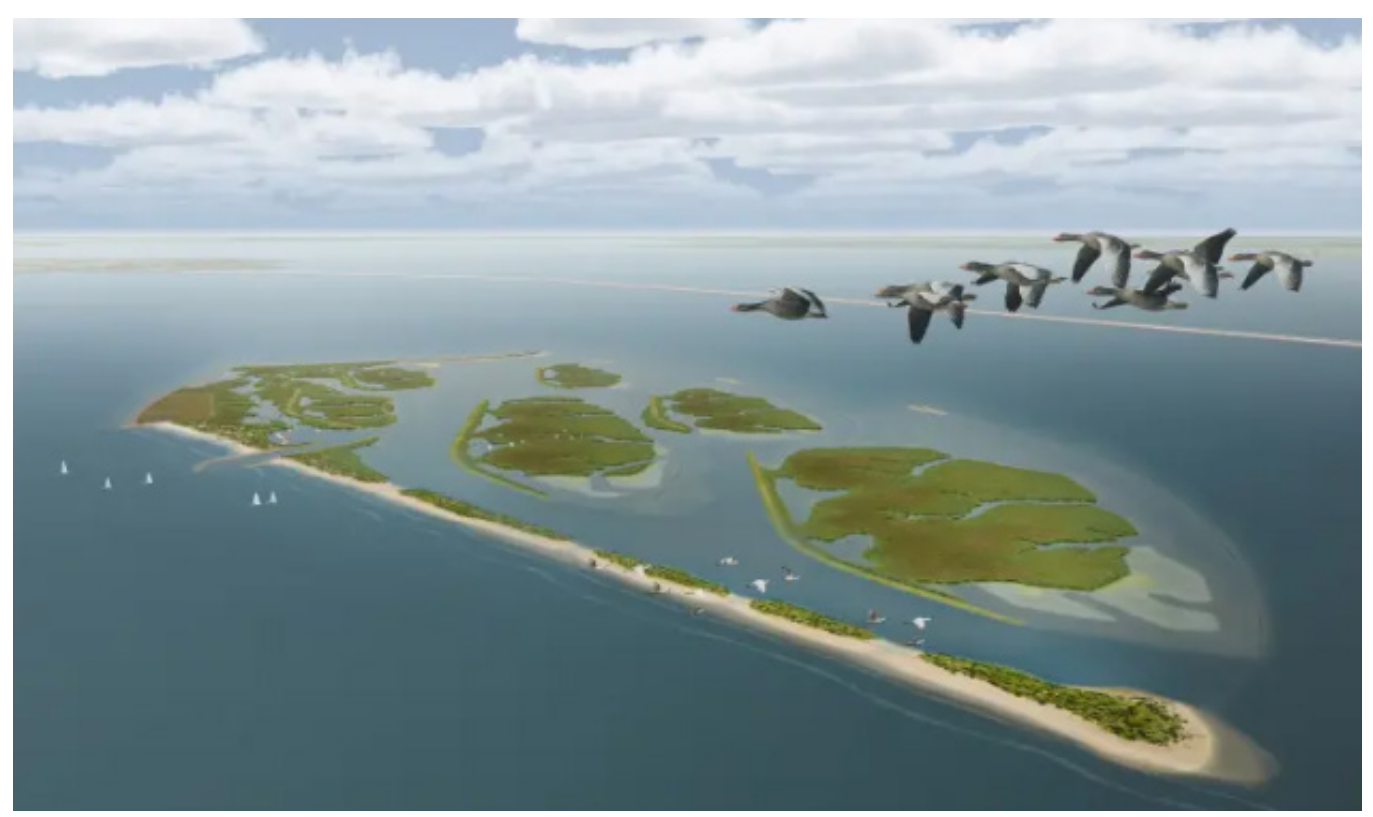

Figuur 9 Zo moeten de Marker Wadden eruit komen te zien (Natuurmonumenten/Boskalis, n.d.).

\subsubsection{Participatie in vergroenen}

Een trend die op het moment aan sterkte wint en die waarschijnlijk in de toekomst door zal zetten, is dat ondernemers en burgers vanuit eigen initiatief hun leefomgeving 'vergroenen', omdat ze het zelf belangrijk vinden (Folkert \& Boonstra, 2017). In andere gevallen participeren burgers actief op uitnodiging van overheden. In 'actie Steenbreek' vervangen bewoners tegels door planten en dat zorgt ervoor dat water in de bodem kan infiltreren. Dit verkleint de kans op wateroverlast. Een ander voorbeeld is de participatie bij de verbetering van de Grebbedijk. Hier hebben bewoners, instellingen, ondernemers en organisaties meegedacht over oplossingsrichtingen voor deze dijk. Deze zogenaamde 'dijkdenkers' hebben een advies voor de dijkverbetering opgesteld (Deltaprogramma, 2019). 


\subsection{Voedsel/landbouw}

Ook voor het thema voedsel en landbouw zijn er handelingsperspectieven. In dit hoofdstuk zal eerst aandacht besteed worden aan gedragsverandering op het gebied van voedsel en daarna zal de kringlooplandbouw behandeld worden. Ten slotte wordt er aandacht besteed aan nieuwe vormen van landbouw.

\subsubsection{Gedragsverandering}

Eten en drinken hebben we nodig, maar het maakt veel verschil voor het watergebruik wat we eten en drinken. Voor de productie van een liter frisdrank is bijvoorbeeld ongeveer 100 liter schoon zoetwater nodig (Hoekstra \& Prast, 2016). Ook de productie van vlees kost veel water; $46 \%$ van onze watervoetafdruk bestaat uit dierlijke producten (Blom et al., 2010). Wie op een dag geen vlees eet en een glas frisdrank vervangt door water, bespaart 800 liter water; evenveel als 40 keer korter douchen (Hoekstra \& Prast, 2016). Er zijn dus veel mogelijkheden om water te besparen door andere keuzes te maken op het gebied van eten en drinken.

\subsubsection{Kringlooplandbouw}

Kringlooplandbouw is al genoemd in hoofdstuk 4. Deze nieuwe ontwikkeling kan zorgen voor een betere verbinding van landbouw en natuur; gebruik van biodiversiteit in de bodem werkt mee aan het sluiten van kringlopen. In de natuur bestaat namelijk geen afval; dode organismen zijn voedsel voor andere organismen (Smits \& Linderhof, 2015). Daarnaast kunnen er in landbouwgebieden natuurwaarden gerealiseerd worden (Schouten, 2018). Daarvoor is natuurinclusieve landbouw nodig, waarbij het accent ligt op het verbeteren van natuur via de landbouw en omgekeerd, door natuur in te zetten voor de landbouw (Rijksoverheid, 2018b).

Verder lezen: Schouten, C. (2018). Landbouw, natuur en voedsel, waardevol en verbonden. Nederland als koploper in kringlooplandbouw. Retrieved from https://www.rijksoverheid.nl/documenten/beleidsnota-s/2018/09/08/visie-landbouw-natuuren-voedsel-waardevol-en-verbonden

\subsubsection{Andere landbouwvormen}

Landbouw is aan de ene kant erg afhankelijk van een stabiel klimaat, maar draagt aan de andere kant bij aan klimaatverandering door de broeigasgassen uit bemesting. Er kan ook koolstof vast worden gelegd door de landbouw (Sociaal-Economische Raad, 2018). Dit gebeurt door vastlegging van koolstof door plantengroei en opslag van koolstof als organische stof in de bodem. In 'climate-smartagriculture' worden adaptatie en mitigatie gecombineerd (Torquebiau, Tissier \& Grosclaude, 2016). Een voorbeeld hiervan is een programma dat gestart is in Delfland, met als doel om in 2027 emissieloze kassen te hebben in de tuinbouwsector (Van Peperstraten, 2018). Andere oplossingsrichtingen zijn het toepassen van strokenteelt om landbouwsystemen weerbaarder te maken tegen ziektes en plagen en nieuwe vormen van zilte landbouw in westelijke gebieden die te maken hebben met zoutindringing. 


\subsection{Klimaatverandering}

De verandering van het klimaat is een serieus probleem waarvan de gevolgen in ons dagelijks leven al te merken zijn en dat zal in de toekomst doorzetten. De gevolgen kunnen beperkt worden wanneer iedereen zich inzet voor een leefbare wereld voor toekomstige generaties. In dit hoofdstuk zal duidelijk worden op welke manieren dit kan en wat het handelingsperspectief is op dit gebied.

\subsubsection{Mitigatie}

De eerste en meest voor de hand liggende stap in het tegengaan van klimaatverandering is het verminderen van de uitstoot van broeikasgassen. Natuurlijk is het van belang dat er wereldwijd tussen overheden afspraken gemaakt worden over de beperking van de uitstoot en is het nodig dat grote en kleine bedrijven actie ondernemen. Maar voor individuele burgers (inclusief kinderen) zijn er ook genoeg mogelijke acties om de uitstoot te verminderen. Om er een paar te noemen:

- Maak minder of geen gebruik van het vliegtuig;

- Koop groenten en fruit van het seizoen, zodat er minder uit andere landen hoeft te komen;

- Eet minder vlees en zuivel;

- Hergebruik of repareer spullen en kleding in plaats van nieuwe aankopen te doen.

Deze maatregelen zijn zowel positief voor het verminderen van de $\mathrm{CO}_{2}$-uitstoot als voor het watergebruik. Daarbij is het belangrijk om bewustzijn te creëren voor consequenties van onze acties en ons gebruik van grondstoffen, waaronder water, en hoe vaak de gevolgen daarvan terechtkomen in gebieden die al met waterschaarste kampen.

\section{Ethisch waterbeheer}

Bij waterkwesties kunnen allerlei ethische vragen gesteld worden. Hoe verenigen we maatregelen bij droogte met maatregelen tegen overstromingen? Hoe zwaar weegt het individuele belang van inwoners en bedrijven bij ingrepen die een groot beslag doen op schaarse ruimte? Hoe verdelen we de risico's en verantwoordelijkheden tussen de overheid en de burger? Hoogleraar Neelke Doorn van de TU Delft bekleedt de eerste leerstoel wereldwijd die zich richt op de ethische aspecten van waterbeheer (Het Waterschap, 2018). Bij zeespiegelstijging spelen ook ethische dilemma's. Beschermen en behouden we koste wat kost de kustlijn of laten we de natuur haar gang gaan? Dit soort vragen zal steeds meer gaan spelen richting 2050.

\subsubsection{Adaptatie}

Het idee dat we, zelfs als we onze broeikasgasemissie weten te beperken, ons zullen moeten aanpassen aan een veranderend klimaat wordt steeds meer geaccepteerd (Kwadijk et al., 2010). Dit wordt adaptatie genoemd: de vermindering van kwetsbaarheid van menselijke en natuurlijke systemen voor klimaatverandering (Javeline et al., 2019). Opties voor adaptatie zijn preventie van rampen of schade, het opbouwen van reactievermogen en het beperken van de gevolgen van schade als er toch een ramp gebeurt (European Commission, 2018). Adaptatie is essentieel, maar er is een aantal obstakels dat het moeilijker maakt om het ook daadwerkelijk toe te passen. Een belangrijk obstakel is het feit dat er sprake is van 'botsende tijdschalen'; klimaatveranderingen gaan relatief langzaam in verhouding tot de kortere termijn planning van overheden, terwijl juist de overheid een belangrijke rol zou moeten spelen in het tegengaan van deze veranderingen (Biesbroek, Klostermann, Termeer \& Kabat, 2011). 
Doorbraakvrije dijken (ook wel klimaatdijken) kunnen gedefinieerd worden als 'dijken die keren tot de kruin en ook bij grote hoeveelheden overslag en/of overloop niet bezwijken' (Klijn,

Van der Doef, \& Asselman, 2014). Deze dijken hoeven minder hoog te zijn, maar moeten wel heel sterk zijn. Meestal gebeurt dat door een bredere dijk aan te leggen. Voordelen zijn dat er minder water het achterdijkse gebied in loopt en dat dit minder snel en plotseling gebeurt. Het water loopt ook voor een kortere tijd over, omdat dit alleen gebeurt gedurende de hoge waterstanden bij vloed; wanneer de dijk doorbreekt, kan dit ook bij eb nog doorgaan (Klijn et al., 2014). De rivierdijk langs de Lek bij Streefkerk is veranderd in een klimaatdijk. In plaats van de conventionele methode van ophogen en verbreden van de binnenberm is er een buitendijkse verbreding van de dijk gerealiseerd. De dijk is op deze manier 100 keer veiliger (De Moel et al., 2010). 


\section{Procesadvies}

Doel van dit deeladvies was vooral de trends en thema's in kaart te brengen die relevant zijn om terug te laten komen in tentoonstellingen in het museum. De manier waarop de thema's over het voetlicht kunnen worden gebracht, wordt in de volgende fase van dit project verder onderzocht. In de twee workshops en de interviews zijn we toch enkele nuttige adviezen tegengekomen die het noemen waard zijn. Dit hoofdstuk is verdeeld in een deel met aanbevelingen op het gebied van inhoud en boodschap en een deel dat focust op externe relaties en de positie ten opzichte van andere musea.

\subsection{Intern - boodschap en monitoring}

Water is op verschillende manieren en in verschillende functies teruggekomen in de voorgaande hoofdstukken. Centraal staat dat water een onmisbaar, maar ook mooi onderdeel is van Nederland, en dat we zuinig met schoon water om moeten gaan. Dit is een belangrijke boodschap voor de museumbezoeker. Hierbij past een basistentoonstelling van mens naar wereld en terug. Je begint bij wie je nu bent en na de reis ben je een beetje veranderd en kies je een ander handelingsperspectief. Dit wordt ook wel 'customer journey' of 'klantreis' genoemd; dit concept wordt steeds meer gebruikt in musea (Versdenkers, 2017). Hierbij is het belangrijk om de bezoeker niet als een anonieme 'customer' te behandelen, maar je in te leven in de percepties van een bezoeker vanaf het moment dat deze contact maakt met het museum tot en met de wandeling door het museum.

Vanuit een basistentoonstelling kunnen elementen uitgewerkt worden voor wisseltentoonstellingen of activiteiten. Kleinere onderwerpen die terug zijn gekomen in het inhoudelijke deel van dit rapport (zoals de onderwerpen in de kaders) kunnen gebruikt worden voor deze wisseltentoonstellingen. Een modulaire opbouw geeft daarbij flexibiliteit: alle onderdelen zijn kralen van een ketting die op verschillende manieren aaneen te rijgen zijn. Ook zou in het museum een display geplaatst kunnen worden met de nieuwste innovatieprijzen op het gebied van water, bijvoorbeeld de waternetwerkscriptieprijs voor scripties over wateronderwerpen of de Global Water Awards voor innovatieve initiatieven in de watersector.

Het is belangrijk om van de verschillende onderdelen te monitoren hoe succesvol ze zijn (hoe vaak bezocht, wat steekt men ervan op) en om vervolgens minder succesvolle onderdelen plaats te laten maken voor vernieuwing. Succesvolle, tijdelijke tentoonstellingen zouden een permanente plek in het museum kunnen krijgen. Omdat ontwikkelingen snel kunnen gaan, is het goed om ongeveer elke vijf jaar een commissie vanuit wetenschap, watersector en onderwijs opnieuw naar de strategie te laten kijken. Wanneer een IPCC-rapport uitgegeven wordt in 2021 is dat ook een goed moment om tentoonstellingen over klimaat te evalueren. Het KNMI brengt na de uitgave van de IPCC een rapport uit met de consequenties voor Nederland. Ten slotte kan het nuttig zijn om het Jeugdjournaal in de gaten te houden voor items die relevant zijn voor het Watermuseum. Deze items zouden gebruikt kunnen worden in publiciteit voor het museum.

Verder lezen: Versdenkers. (2017). Wat kunnen musea nou met storytelling? Focus op beleving, participatie en spreadability. Retrieved from https://versdenkers.nl/focus-opbeleving-participatie-en-spreadability/ 


\subsection{Extern - pop-up en communicatie}

Tijdelijke tentoonstellingen, wellicht ook buitenshuis/op locatie, kunnen gebruikt worden als pop-uptentoonstellingen of teasers (in andere musea) om aandacht te trekken voor het Watermuseum. Op deze manier kan uitwisseling met andere musea plaatsvinden. Een andere manier om meer mensen buiten het museum te bereiken, is het organiseren van excursies in de regio (met partners), bijvoorbeeld kanotochten of kunstworkshops. Ook is het belangrijk om te bedenken wat het museum onderscheidend maakt, hoe dit onder de aandacht kan worden gebracht en hoe dit vorm kan krijgen in het museum. Er kan bijvoorbeeld geprobeerd worden het museum als gebouw zelf ook klimaatbestendig te maken. 


\section{Literatuur}

Baggelaar, Paul K. en Peter J.J.G. Geudens (2017) Prognoses en scenario's drinkwatergebruik in Nederland, Icastat /Vewin, Retrieved from

https://www.vewin.nl/SiteCollectionDocuments/Publicaties/Cijfers/Rapport\%20Prognoses\%20en\% 20scenarios\%20drwgebruik\%20NL.pdf

Berge, A. P. v. d., Groen, K., Havekes, H. J. M., Hofstra, M. A., \& Teulings, J. H. A. (Eds.). (1995). Bestrijding van de watervervuiling, vijfentwintig jaar WVO. Den Haag: Unie van Waterschappen.Biesbroek, R., Klostermann, J., Termeer, C., \& Kabat, P. (2011). Barriers to climate change adaptation in the Netherlands. Climate Law, 2(2011), 181 - 199. doi:10.3233/CL2011-033

Bijl, D. L., Biemans, H., Bogaart, P. W., Dekker, S. C., Doelman, J. C., Stehfest, E., \& van Vuuren, D. P. (2018). A Global Analysis of Future Water Deficit Based On Different Allocation Mechanisms. Water Resources Research, 54(8), 5803-5824. doi:10.1029/2017wr021688

Blom, Esther, Monique Grooten, Marieke van Zalk, Natascha Zwaal, Baud Schoenmaeckers (2010) Water - een kostbaar goed. De Nederlandse watervoetafdruk nader bekeken Wereld Natuur Fonds, Zeist http://assets.wnf.nl/downloads/waterrapport_wnf_web.pdf

Bodemdalingskaart.nl. (2019). Actuele Bodemdalingskaart Nederland. Retrieved from https://bodemdalingskaart.nl/

Bromet, L., \& de Groot, T. (2019). Veen red je niet alleen; Initiatiefnota over natuur en klimaat in het veenweidegebied Groenlinks \& D66.

Burroughs, William J. (2001) (Nederlandse vertaling Helga van Leur). Het klimaat onthuld. Uitgeverij Schuyt \& Co in samenwerking met wetenschapsmagazine Natuur \& Techniek. ISBN 906097557 X

CBS, PBL, RIVM, \& WUR. (2014). Invloed klimaatverandering op koude- en warmteminnende diersoorten, 1990-2013 (indicator 1429, versie 08). Retrieved from https://www.clo.nl/indicatoren/nl1429-klimaat-en-warmte--en-koudeminnende-soorten

De Moel, H., Beijersbergen, J., van den Berg, F., de Goei, J., Koch, R. C., Koelewijn, A. R., Zantinge, A. M. (2010). De Klimaatdijk in de Praktijk. Utrecht: Kennis voor Klimaat.

De Wit, M., Buiteveld, H., Van Deursen, W., Keller, F., \& Bessembinder, J. (2008). Klimaatverandering en de afvoer van Rijn en Maas. Stromingen, 14(1).

Deltanieuws. (2019). De waarde van natuur en water. Deltanieuws. Retrieved from https://magazines.deltacommissaris.nl/deltanieuws/2019/01/ra-congres-bgsenh

Deltaprogramma. (2019). Voortgang van het Deltaprogramma op hoofdlijnen. Retrieved from https://deltaprogramma2019.deltacommissaris. $\mathrm{nl} / 2 . \mathrm{html}$

European Commission. (2018). Evaluation of the EU strategy on adaptation to climate change. Brussels.

Foley, J. (2009). The other inconvenient truth: the crisis in global land use. The Guardian. Retrieved from https://www.theguardian.com/environment/2009/oct/06/global-land-use

Folkert, R., \& Boonstra, F. (2017). Lerende evaluatie van het Natuurpact. Naar nieuwe verbindingen tussen natuur, beleid en samenleving. Den Haag: Uitgeverij PBL.

Groenewegen, Jesse, Lisette van de Hei en Daniël van Schoot, 14 februari 2017. Nederlandse economie vertoont solide groei in vierde kwartaal van 2016. Economisch commentaar, Rabobank. https://economie.rabobank.com/publicaties/2017/februari/nederlandse-economie-vertoont-solidegroei-in-vierde-kwartaal-van-2016/

Haastregt, B. (2018). Evaluatie Droge Zomer 2018 Waterkeringen. Amersfoort: Stichting Toegepast Onderzoek Waterbeheer.

Hardelin, J., \& Lankoski, J. (2015). Climate Change, Water \& Agriculture, Challenges \& Adapation Strategies. EuroChoices, 14(2), 10-15.

Hartgers, Elizabeth, Michael van Buuren, Robert Jan Fontein, Tim van Hattum, Marieke de Lange en Gilbert Maas, 2015. Natuurrealisatie in het programma Ruimte voor de Rivier. Alterra, Wageningen. https://library.wur.nl/WebQuery/wurpubs/fulltext/367526

Het Waterschap. (2018). Ethisch waterbeheer. Het Waterschap, 12(10), 33. 
Hoekstra, A., \& Prast, H. (2016). Water besparen? Korter douchen helpt niet. NRC. Retrieved from https://www.nrc.nl/nieuws/2016/11/16/water-besparen-korter-douchen-helpt-niet-5317549a1532071

Hoenderdos, K. (2015). Wat is het juiste vochtpercentage? Retrieved from https://www.gezondheidsnet.nl/overgewicht-en-afvallen/wat-is-het-juiste-vochtpercentage

Interprovinciaal Overleg. (2017). Derde voortgangsrapportage Natuur-. Provinciaal natuurbeleid in uitvoering in 2016-. Rijswijk: De Resolutie.

IPCC. (2014). Climate change 2014 - Impacts, Adaptation \& Vulnerability, Part A: Global and Sectoral Aspects New York: Cambridge University Press.

Javeline, D., Dolšak, N., \& Prakash, A. (2019). Adapting to water impacts of climate change. Climatic Change, 152(2), 209-213. doi:10.1007/s10584-018-2349-1

Klein Tank, A., Beersma, J., Bessembinder, J., van den Hurk, B., \& Lenderink, G. (2015). KNMI'14 Climate scenarios for the Netherlands. Zwolle: Zalsman B.V.

Klijn, F., van der Doef, M., \& Asselman, N. (2014). Doorbraakvrije dijken, een nadere verkenning. Utrecht: Nationaal Onderzoeksprogramma Kennis voor Klimaat (KvK) \& Deltares.

KNMI. (2012). Extreem weer en klimaatverandering. Retrieved from https://www.knmi.nl/kennis-endatacentrum/achtergrond/extreem-weer-en-klimaatverandering

KNMI. (2018). Trends in weerextremen in Nederland. Retrieved from https://www.knmi.nl/over-hetknmi/nieuws/trends-in-weerextremen-in-nederland

KNMI. (2019). Uitleg over regen. Retrieved from https://www.knmi.nl/kennis-endatacentrum/uitleg/regen

Kwadijk, J. C. J., Haasnoot, M., Mulder, J. P. M., Hoogvliet, M. M. C., Jeuken, A. B. M., van der Krogt, R. A. A., . . . de Wit, M. J. M. (2010). Using adaptation tipping points to prepare for climate change and sea level rise: a case study in the Netherlands. Wiley Interdisciplinary Reviews: Climate Change, 1(5), 729-740. doi:10.1002/wcc.64

Lenntech. (n.d.). Water weetjes en feiten. Retrieved from https://www.lenntech.nl/water-triviafeiten.htm

Livescience (2017) How Long Can a Person Survive Without Water? Retrieved from https://www.livescience.com/32320-how-long-can-a-person-survive-without-water.html

Lovelock, J. (1979). Gaia: A New Look at Life on Earth. Oxford: Oxford University Press.

Meijs, S., Arbouw, G., de Graaff, R., de Helden-Solleveld, T., Helmer, M., van Hemert, P., . . . van Zeggeren, B. (2018). Uitvoeren met ambitie; Uitvoeringsprogramma 2018-2019 Nationale klimaatadaptatiestrategie. Den Haag: Ministerie van Infrastructuur en Waterstaat.

Ministerie LNV. (2019). Realisatieplan Visie LNV: Op weg met nieuw perspectief. Den Haag: Ministerie LNV.

Morgan, R. A. (2018). Climate, weather, and water in history. Wiley Interdisciplinary Reviews: Climate Change, 10(1). doi:10.1002/wcc.561

Muntendam-Bos, A. G., Kroon, I. C., Fokker, P. A., \& Lange, G. d. (2006). Bodemdaling in Nederland. Den Haag: TNO Geologische Dienst Nederland.

Natuurmonumenten. (n.d.). Marker Wadden. Retrieved from https://www.natuurmonumenten.nl/projecten/marker-wadden

NCG. (2019). Actuele Bodemdalingskaart Nederland. Retrieved from https://bodemdalingskaart.nl/

NEMO Kennislink. (2014). Oude doos herbergt vergeten oersoep-experiment. Retrieved from https://www.nemokennislink.nl/publicaties/oude-doos-herbergt-vergeten-oersoep-experiment/

NEMO Kennislink. (2016). Hoe is de eerste cel ontstaan? Retrieved from https://www.nemokennislink.nl/publicaties/hoe-is-de-eerste-cel-ontstaan/

Netherlands Ecological Research Network. (2018). Deltaplan Biodiversiteitsherstel. In actie voor een rijker Nederland. Wageningen: NERN.

NRC. (2019). Hoe is het stikstofprobleem ontstaan en 12 andere vragen. https://www.nrc.nl/nieuws/2019/12/17/hoe-is-het-stikstofprobleem-ontstaan-en-12-anderevragen-a3984095

Olde Wolbers, M., Das, L., Wiltink, J., \& Brave, F. (2018). Eindevaluatie Ruimte voor de Rivier. Sturen en ruimte geven Utrecht: Berenschot.

Oude Essink, G. H. P., van Baaren, E. S., \& de Louw, P. G. B. (2010). Effects of climate change on coastal groundwater systems: A modeling study in the Netherlands. Water Resources Research, 46(10). doi:10.1029/2009wr008719 
PBL, 2012. Klimaatverandering -stand van de wetenschap. KNMI, De Bilt; PBL, Bilthoven. https://www.pbl.nl/sites/default/files/downloads/PBL-2012-KNMI-Wilco-HazelegerKlimaatverandering-stand-van-de-wetenschap.pdf

$\mathrm{PBL}$, 2018. Balans van de Leefomgeving 2018, PBL, Bilthoven. https://themasites.pbl.nl/balansvandeleefomgeving/jaargang-2018/themas/verstedelijkingwonen/ontwikkeling-woningvoorraad

Rijksoverheid. (2018a). Export landbouwproducten in 2017 bijna $€ 92$ miljard. Retrieved from https://www.rijksoverheid.nl/actueel/nieuws/2018/01/19/export-landbouwproducten-in-2017bijna-\%E2\%82\%AC-92-miljard

Rijksoverheid. (2018b). Kabinetsperspectief NOVI. Den Haag Ministerie van Binnenlandse Zaken en Koninkrijksrelaties.

Roser, Max, Hannah Ritchie and Esteban Ortiz-Ospina, 2019, World Population Growth. Our World in Data, First published in 2013; most recent substantial revision in May 2019. https://ourworldindata.org/world-population-growth

RTV Oost, vrijdag 8 februari. https://www.rtvoost.nl/nieuws/307116/Deventer-klimaatmeisjes-stakenstug-door-ook-na-lange-actiedag-Den-Haag

Schouten, C. (2018). Landbouw, natuur en voedsel, waardevol en verbonden. Nederland als koploper in kringlooplandbouw. Den Haag: Ministerie van Landbouw, Natuur en Voedselkwaliteit.

Schuwer, D. (2007). Wonen op het water, succes- en faalfactoren. Een onderzoek naar 5 case studies met waterwoningen. (Landscape architecture and spatial planning), Wageningen University \& Research,

Silva, W., \& van Velzen, E. (2008). De dijk van de toekomst? Quick scan doorbraakvrije dijken. Den Haag: Rijkswaterstaat \& Deltares.

Smit, M., Oosterhuis, F., van Kreveld, A., \& Braakhekke, W. (2014). Natuur als partner bij klimaatadaptatie. Een procesevaluatie van tien klimaatbufferprojecten. Retrieved from Den Haag:

Smits, M., \& Linderhof, V. (2015). Circulaire economie in de landbouw, een overzicht van concrete voorbeelden in Nederland. Wageningen: LEI Wageningen UR.

Sociaal-Economische Raad. (2018). Ontwerp van het Klimaatakkoord. Den Haag: Sociaal-Economische Raad.

Stichting Deltawerken Online. (2004). De Waterkringloop. Retrieved from http://www.deltawerken.com/De-waterkringloop/85.html

The Footprint Challenge. (2017). Wereld Waterdag en de watervoetafdruk. Retrieved from https://www.footprintchallenge.nl/wereld-water-dag-en-jouw-watervoetafdruk/

Torquebiau, E., Tissier, J., \& Grosclaude, J.-Y. (2016). How Climate Change Reshuffles the Cards for Agriculture. In Climate Change and Agriculture Worldwide (pp. 1-16).

Turral, H., Burke, J., \& Faurès, J. (2011). Climate change, water and food security. Rome: Food and Agriculture Organization of the United Nations.

Union of Concerned Scientists. (n.d.). Water and Climate Change. Retrieved from https://www.ucsusa.org/global-warming/science-and-impacts/impacts/water-and-climatechange.html

van Gaalen, F., Tiktak, A., Franken, R., Boekel, v., E., van Puijenbroek, P., \& Muilwijk, H. (2015). Waterkwaliteit nu en in de toekomst. Eindrapportage ex ante evaluatie van de Nederlandse plannen voor de Kaderrichtlijn Water. Den Haag: PBL

van Peperstraten, J. (2018). Emissieloze kas in zicht. Het Waterschap, 12(10), 24-25.

Van Raaij, Leo, 21-09-18. Droogte in Twente: de zomer van 2018 was een reality check. Tubantia. Foto Droogte in Markelo: Eric Brinkhorst https://www.tubantia.nl/regio/droogte-in-twente-dezomer-van-2018-was-een-reality-check aed529af/

Vermeulen, S. J., Campbell, B. M., \& Ingram, J. S. I. (2012). Climate Change and Food Systems. Annual Review of Environment and Resources, 37(1), 195-222. doi:10.1146/annurev-environ020411-130608

Versdenkers. (2017). Wat kunnen musea nou met storytelling? Focus op beleving, participatie en spreadability. Retrieved from https://versdenkers.nl/focus-op-beleving-participatie-enspreadability/

Verweij, W., van der Wiele, J., van Moorselaar, I., \& van der Grinten, E. (2010). Impact of climate change on water quality in the Netherlands. Bilthoven: RIVM.

Vonk, M., Bouwman, A., van Dorland, R., \& Eerens, H. (2015). Wereldwijde klimaateffecten: risico's en kansen voor Nederland. Den Haag: Uitgeverij PBL. 
Water Footprint Network. (n.d.). What is a water footprint? Retrieved from https://waterfootprint.org/en/water-footprint/what-is-water-footprint/

Waternet. (n.d.). Weetjes. Retrieved from https://www.waternet.nl/ons-water/leren-overwater/waternet-op-school/waterfanaten/weetjes/

Wikipedia. (2019). Abiogenese. Retrieved from https://nl.wikipedia.org/wiki/Abiogenese

World Atlas. (2017). The Water Cycle. Retrieved from https://www.worldatlas.com/the-watercycle.html

World Bank. (2009). World Development Report 2010: Development and Climate Change. Washington: World Bank. 


\section{Bijlage 1 Vragenlijst bezoekers}

\section{Vragenlijst}

Dit is een onderzoek voor mijn ${ }^{1}$ stage bij Wageningen Environmental Research in het kader van mijn master in Climate Studies, met als doel het schrijven van een toekomstvisie voor het Nederlands Watermuseum. De resultaten van deze vragenlijsten zullen bijdragen aan de afbakening van de te beschrijven onderwerpen in de toekomstvisie. De gegevens zullen vertrouwelijk behandeld worden.

1 Wat is je leeftijd?
$00-20$
O $21-30$
O $31-50$
O $51-70$
O $70+$
O Wil ik niet beantwoorden

2 Wat is je geslacht?
O Man
O Vrouw
O Wil ik niet beantwoorden

3 Hoe vaak ben je in het Nederlands Watermuseum geweest?
$O$ Dit is/was de eerste keer
O 2 - 3 keer
O 4 - 5 keer
O Vaker dan 5 keer

4 Het museum wil mee gaan met ontwikkelingen in de huidige tijd. Binnen de onderstaande thema's zijn belangrijke ontwikkelingen gaande die met water te maken hebben. Welke onderwerpen vind jij belangrijk om in de toekomst terug te zien in het museum? (maximaal 2)
O Economie
O Ruimte/natuur
O Technologie
O Demografie
O Klimaat
O Voedsel/landbouw
O Anders, namelijk:

\footnotetext{
${ }^{1}$ Naomi Kroon
} 
5 Op welk schaalniveau zou je deze ontwikkelingen terug willen zien in het museum? (kies 1)
O Wereld
O Nederland
O Eigen regio
O Anders, namelijk:

6 Op welke manier zie jij gevaren/problemen op het gebied van water in Nederland voor de toekomst?

7 Heb je nog opmerkingen of aanbevelingen voor de verbetering van het museum in de toekomst?

Bedankt voor je medewerking! 


\section{Bijlage 2 Resultaten vragenlijsten bezoekers}

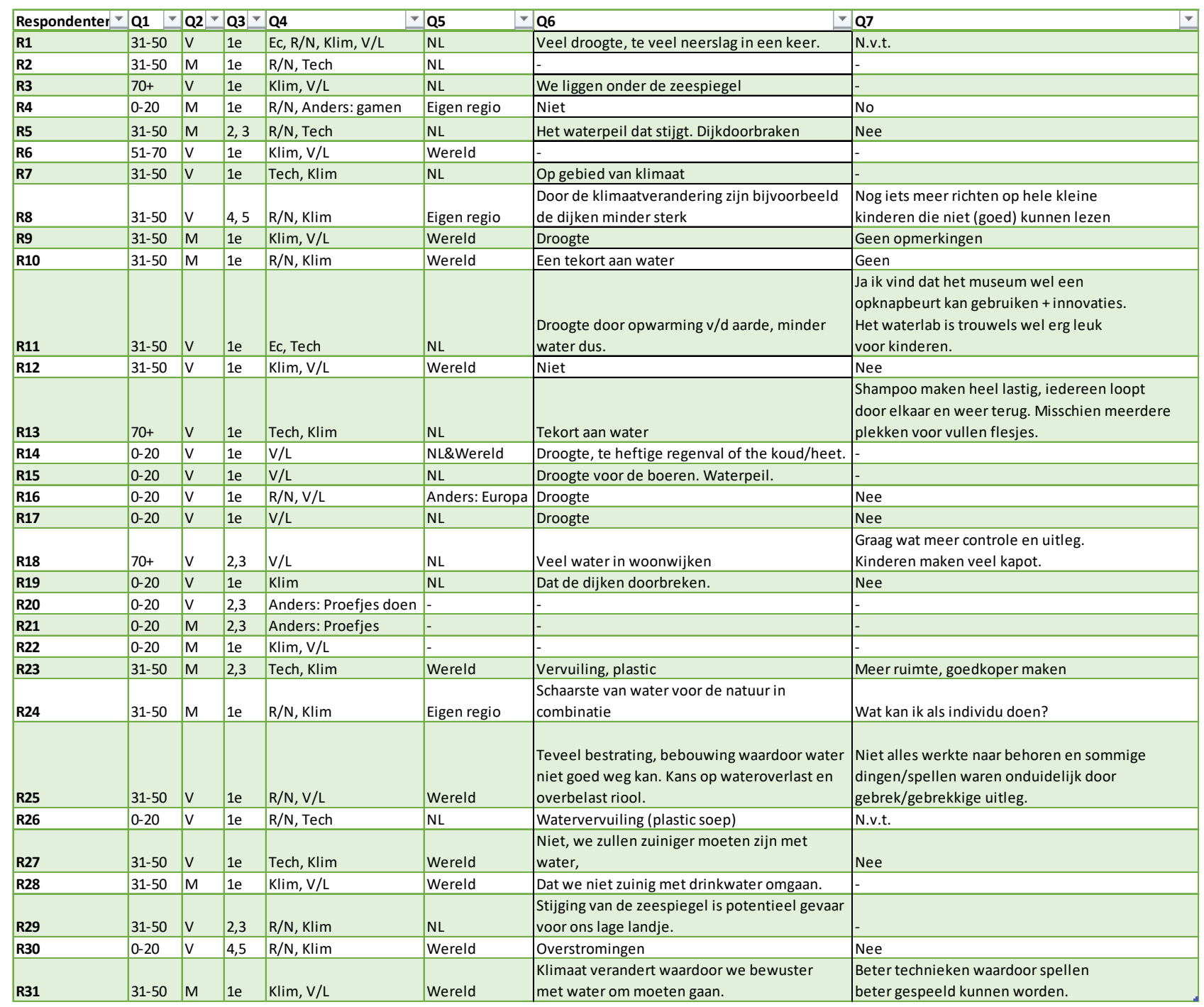


Wageningen Environmental Research Postbus 47

6700 AA Wageningen

T 0317480700

www.wur.nl/environmental-research

Wageningen Environmental Research Rapport 3022

ISSN 1566-7197
De missie van Wageningen University \& Research is 'To explore the potential of nature to improve the quality of life'. Binnen Wageningen University \& Research bundelen Wageningen University en gespecialiseerde onderzoeksinstituten van Stichting Wageningen Research hun krachten om bij te dragen aan de oplossing van belangrijke vragen in het domein van gezonde voeding en leefomgeving. Met ongeveer 30 vestigingen, 5.000 medewerkers en 12.000 studenten behoort Wageningen University \& Research wereldwijd tot de aansprekende kennisinstellingen binnen haar domein. De integrale benadering van de vraagstukken en de samenwerking tussen verschillende disciplines vormen het hart van de unieke Wageningen aanpak. 



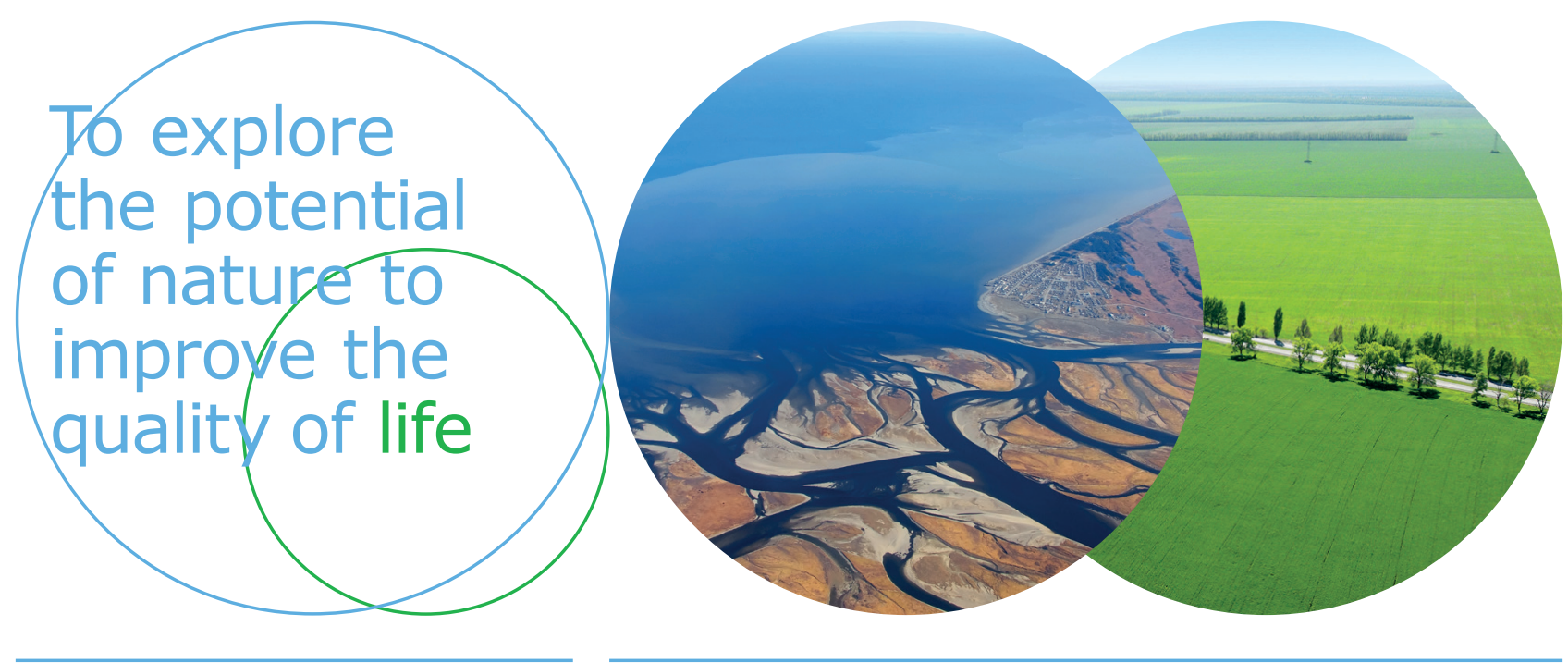

Wageningen Environmental Research Postbus 47

$6700 \mathrm{AB}$ Wageningen

T 317480700

www.wur.nl/environmental-research

Rapport 3022

ISSN 1566-7197
De missie van Wageningen University \& Research is 'To explore the potential of nature to improve the quality of life'. Binnen Wageningen University \& Research bundelen Wageningen University en gespecialiseerde onderzoeksinstituten van Stichting Wageningen Research hun krachten om bij te dragen aan de oplossing van belangrijke vragen in het domein van gezonde voeding en leefomgeving. Met ongeveer 30 vestigingen, 5.000 medewerkers en 12.000 studenten behoort Wageningen University \& Research wereldwijd tot de aansprekende kennisinstellingen binnen haar domein. De integrale benadering van de vraagstukken en de samenwerking tussen verschillende disciplines vormen het hart van de unieke Wageningen aanpak. 